\title{
Role of specificity protein transcription factors in estrogen- induced gene expression in MCF-7 breast cancer cells
}

\author{
Shaheen Khan ${ }^{1}$, Fei Wu${ }^{2}$, Shengxi Liu ${ }^{3}$, Qian $\mathrm{Wu}^{2}$ and Stephen Safe ${ }^{1,3}$ \\ Departments of ${ }^{1}$ Veterinary Physiology and Pharmacology and ${ }^{2}$ Biochemistry and Biophysics, Texas A \& M University, College Station, Texas 77843-4466, USA \\ ${ }^{3}$ The Institute of Biosciences and Technology, Texas A \& M University Health Science Center, 2121 West Holcombe Boulevard, Houston, Texas 77030, USA \\ (Correspondence should be addressed to S Safe; Email: ssafe@cvm.tamu.edu)
}

\begin{abstract}
Deletion analysis of several $17 \beta$-estradiol $\left(\mathrm{E}_{2}\right)$-responsive genes have identified GC-rich sites that are associated with hormone-induced transactivation in MCF-7 breast cancer cells. However, the role of individual specificity proteins (Sps) in mediating hormone-induced gene expression has not been unequivocally determined. In transient transfection studies using $\mathrm{E}_{2}$-responsive $\mathrm{GC}$-rich promoters from the $\mathrm{E}_{2} \mathrm{~F} 1$, carbamoylphosphate synthetase/aspartate transcarbamylase/dihydroorotase (CAD), and retinoic acid receptor $\alpha(\mathrm{RAR} \alpha)$ genes, RNA interference using small inhibitory RNAs for Sp1 (iSp1), Sp3 (iSp3), and Sp4 (iSp4) decreased both basal and $E_{2}$-induced transactivation. The contributions of individual Sp proteins to basal and $E_{2}$-induced activity were promoter dependent. iSp1, iSp3, and iSp4 also significantly inhibited hormonal induction of $\mathrm{E}_{2} \mathrm{~F} 1, \mathrm{CAD}$, and RAR $\alpha \mathrm{mRNA}$ levels; however, the enhanced inhibitory effects of the latter two small inhibitory RNAs suggest that Sp3 and Sp4 play a major role in estrogen receptor $\alpha / \mathrm{Sp}$-mediated gene expression in MCF-7 cells.
\end{abstract}

Journal of Molecular Endocrinology (2007) 39, 289-304

\section{Introduction}

The estrogen receptor (ER) is a member of the nuclear receptor superfamily of transcription factors and is required for mediating $17 \beta$-estradiol $\left(\mathrm{E}_{2}\right)$-induced responses in multiple tissues and organs (Chow et al. 1992, Turner et al. 1994, Farhat et al. 1996, Clark 1998). Two major ER subtypes (ER $\alpha$ and ER $\beta$ ) and multiple splice variants have been identified and these various forms exhibit both overlapping and different activities (Hall et al. 2001, Olefsky 2001, Nilsson \& Gustafsson 2002, Matthews \& Gustafsson 2003). ER $\alpha$ and ER $\beta$ exhibit the typical domain structures of nuclear receptors, and similarities in their DNA binding $(\mathrm{C})$ and ligand binding (EF) domains are correlated with comparable mechanisms of DNA binding and similar but not identical interactions with various estrogenic ligands (Hall et al. 2001, Olefsky 2001, Nilsson \& Gustafsson 2002, Matthews \& Gustafsson 2003). The N-terminal regions (AB) of human ER $\alpha$ and $\operatorname{ER} \beta$ exhibit only $17 \%$ amino acid homology and this variability may account for some of the differences between the ER subtypes such as those observed in the murine uterus where ER $\beta$ tends to inhibit ER $\alpha$-dependent uterotrophic responses (Krege et al. 1998, Weihua et al. 2000).

The classical ER mechanism of action involves ligandinduced formation of an ER homodimer which interacts with estrogen responsive elements (EREs; Klein-Hitpass et al. 1986, Cowley et al. 1997, Hyder et al. 1999) in target gene promoters and recruits cofactors necessary for transactivation. There is an increasing evidence that the classical genomic ER-ERE complex formation is only one of several genomic and non-genomic pathways of estrogen action (Blobel \& Orkin 1996, Delfino \& Walker 1999, Kelly \& Wagner 1999, Kushner et al. 2000, Watson et al. 2002, Razandi et al. 2004, Safe \& Kim 2004, Levin 2005). Genomic ER associates with other transcription factors such as the activating protein-1 (AP-1) complex, nuclear factor kappa B (NFKB), and specificity proteins (Sps) to modulate ligand-dependent gene expression. For example, studies in this laboratory and others have demonstrated that deletion and mutational analysis of promoters derived from several $\mathrm{E}_{2}$-responsive genes contain GC-rich motifs that bind Sp proteins (Safe \& Kim 2004). Some of the genes that fall into this category are important for cell proliferation, angiogenesis, and nucleotide metabolism and include $\mathrm{E}_{2} \mathrm{~F} 1$, retinoic acid receptor $\alpha(\mathrm{RAR} \alpha)$, carbamoylphosphate synthetase/ aspartate transcarbamylase/dihydroorotase (CAD), bcl2 , DNA polymerase $\alpha$, vascular endothelial growth factor (VEGF), VEGFR receptor 2 (VEGFR2), progesterone receptor, creatine kinase $B$, thymidylate synthase, insulinlike growth factor binding protein 4, epidermal growth factor receptor, receptor for advanced glycation end products, low density lipoprotein receptor, vitamin D receptor, pS2, LRP16, metastasis associated protein 3, and SK3 (Porter et al. 1996, 1997, Duan et al. 1998, Sun et al. 1998, 2005, Dong et al. 1999, Qin et al. 1999, Wang et al. 1999, 2002, Xie et al. 1999, 2000, Byrne et al. 2000, Salvatori et al. 2000, Saville et al. 2000, Stoner et al. 2000, 2004,

DOI: 10.1677/JME-07-0043 Online version via http://www.endocrinology-journals.org 
Tanaka et al. 2000, Castro-Rivera et al. 2001, Li et al. 2001, Samudio et al. 2001, Bruning et al. 2003, Jacobson et al. 2003, Khan et al. 2003, Ngwenya \& Safe 2003, Schultz et al. 2003, 2005, Fujita et al. 2004, Bardin et al. 2005, Zhao et al. 2005, Higgins et al. 2006b). In addition, RNA interference studies with a small inhibitory RNA (siRNA) for Sp1 (iSp1) show that after transfection with iSpl, there was a significant decrease in hormone-induced $\mathrm{G}_{0} / \mathrm{G}_{1}$ to S-phase progression, suggesting that $\mathrm{ER} \alpha / \mathrm{Sp} 1$ plays an important role in this process (Abdelrahim et al. 2002).

MCF-7 cells express multiple Sp proteins including Sp1, Sp3, and Sp4, and the role of these individual proteins in mediating $\mathrm{E}_{2}$-induced transactivation has not been determined. Using the $\mathrm{E}_{2} \mathrm{~F} 1$ gene as a model, we now show that hormonal activation of a GC-rich $\mathrm{E}_{2} \mathrm{~F} 1$ promoter construct is inhibited in cells cotransfected siRNAs for Sp1, Sp3 (iSp3), and Sp4 (iSp4), and using this approach, it was shown that these Sp proteins are also important for hormone-induced expression of $\mathrm{E}_{2} \mathrm{~F} 1 \mathrm{mRNA}$ and protein. Similar results were observed for two other $\mathrm{E}_{2}$-responsive genes, $\mathrm{CAD}$ and $\mathrm{RAR} \alpha$, demonstrating that all three Sp proteins and particularly Sp3 and Sp4 are important for ER $\alpha /$ Sp-mediated gene expression in MCF-7 cells.

\section{Materials and methods}

\section{Cells, chemicals, biochemicals, and plasmids}

MCF-7 cells were purchased from the American Type Culture Collection (ATCC, Manassas, VA, USA) and were cultured in DME/F12 (Sigma Chemical Co.) media supplemented with $5 \%$ fetal bovine serum (FBS; JRH Biosciences, Lenaxa, KS, USA; or Atlanta Biologicals Inc., Norcross, GA, USA), 1.5 g/l sodium bicarbonate, and $10 \mathrm{ml} / 1$ antibiotic-antimycotic solution (Sigma). Cells were maintained in incubators at $37^{\circ} \mathrm{C}$ under humidified $5 \% \mathrm{CO}_{2}: 95 \%$ air. Dimethyl sulfoxide $\left(\mathrm{Me}_{2} \mathrm{SO}\right)$, PBS, and $\mathrm{E}_{2}$ were purchased from Sigma. Reporter lysis buffer and luciferase assay reagent were purchased from Promega Corp. and/or Boehringer Mannheim. $\beta$-Galactosidase activity was measured using Tropix Galacto-Light Plus assay system (Tropix, Bedford, MA, USA). Instant Imager and Lumicount micro-well plate reader were purchased from Packard Instrument Co. (Downers Grove, IL, USA). B-Actin antibody was obtained from Sigma and all other antibodies were purchased from Santa Cruz Biotechnology (Santa Cruz, CA, USA). Human ER $\alpha$ expression plasmid was originally provided by Dr MingJer Tsai (Baylor College of Medicine, Houston, TX, USA) and was recloned into pcDNA3 in this laboratory. Promoter luciferase construct pRAR $\alpha 2(-79 /-49)$ was made by inserting the oligonucleotide spanning -79 to -49 of the human RAR $\alpha 1$ promoter into the
pGL2 basic luciferase reporter plasmid (Promega Corp). CAD promoter luciferase construct pCAD2 $(-90 /+25)$ was kindly provided by Dr Peggy Farnham (University of Wisconsin, Madison, WI, USA). $\mathrm{E}_{2} \mathrm{~F} 1$ promoter luciferase construct $\mathrm{pE}_{2} \mathrm{~F} 1 \mathrm{~h}$ was made in this laboratory as described (Wang et al. 1999). Plasmid $\mathrm{pSp}_{3}$ containing three consensus Sp1 binding sites linked to a luciferase reporter gene was cloned into pXP2 plasmid in this laboratory.

\section{Transient transfection assays of small inhibitory RNA}

Validated, non-targeting small inhibitory RNA (siRNA; Silencer Negative Control siRNA; iNS1) was purchased from Ambion (Austin, TX, USA) and siRNAs for Sp1, Sp3, and Sp4 were purchased from Dharmacon Research (Lafayette, CO, USA). MCF-7 cells were seeded in DME/F12 medium supplemented with $2.5 \%$ charcoalstripped serum overnight in 12-well plates. After 16-20 h, siRNA duplexes were transfected using Lipofectamine 2000 Reagent (Invitrogen Life Technologies). After 24 h, reporter plasmids (200 ng) were cotransfected with ER $\alpha$ expression plasmid (150 $\mathrm{ng}$ ) and $50 \mathrm{ng}$ pCDNA3.1-HisLacZ using GeneJuice (Novagen, EMD Biosciences Inc., Madison, WI, USA) according to the manufacturer's protocol. Cells were then treated for $36 \mathrm{~h}$ with $\mathrm{Me}_{2} \mathrm{SO}$ or $\mathrm{E}_{2}$ and harvested in $100 \mu \mathrm{l}$ of cell lysis buffer (Promega Corp). Luciferase activities in the various treatment groups were performed on $20 \mu \mathrm{l}$ of cell extract using the luciferase assay system (Promega Corp.) in a luminometer (Packard Instrument Co., Meriden, CT, USA) and results were normalized to $\beta$-galactosidase enzyme activity, which was carried out on $20 \mu$ of cell extract. Sequences of siRNA oligonucleotides for Sp1, Sp3, and Sp4 are summarized below.

Sp1: 5'-AUC ACU CCA UGG AUG AAA UGA dTdT-3'

Sp3: 5'-GCG GCA GGU GGA GCC UUC ACU dTdT-3'

Sp4: 5'-GCA GUG ACA CAU UAG UGA GC dT dT- $3^{\prime}$

\section{Preparation of whole cell extracts and western blot analysis}

MCF-7 cells were seeded into six-well plates in DME/F12 medium supplemented with $2.5 \%$ charcoal-stripped serum. The next day, cells were transfected with siRNAs using Lipofectamine 2000 reagent according to the manufacturer's protocol. After 55-60 h, cells were dosed with $\mathrm{Me}_{2} \mathrm{SO}$ and $\mathrm{E}_{2}$ for $18 \mathrm{~h}$ and then harvested with ice-cold lysis buffer (50 mM HEPES (pH 7.5), $500 \mathrm{mM}$ $\mathrm{NaCl}, 10 \%$ (v/v) glycerol, $1 \%$ Triton X-100, $1.5 \mathrm{mM} \mathrm{MgCl}_{2}$, and $1 \mathrm{mM}$ EGTA) and supplemented with protease inhibitor cocktail (Sigma). Equal amounts of protein from each treatment group were boiled in $1 \times$ sample buffer (50 mM Tris-HCl, 2\% SDS, $0 \cdot 1 \%$ bromphenol blue, 
and $175 \mathrm{mM} \beta$-mercaptoethenol) for $5 \mathrm{~min}$ and separated on 7.5 or $10 \%$ gel, and then transferred to polyvinylidene difluoride membrane (Bio-Rad) overnight at $30 \mathrm{~V}$. Membranes were blocked in Blotto (5\% milk, Tris-buffered saline (10 mM Tris- $\mathrm{HCl}(\mathrm{pH} 8 \cdot 0)$ and $150 \mathrm{mM} \mathrm{NaCl})$, and $0.05 \%$ Tween 20) for $30 \mathrm{~min}$ and probed with primary antibodies for $2-4 \mathrm{~h}$. Membranes were washed for $30 \mathrm{~min}$ in $1 \times$ TBS-Tween, probed with peroxidase-conjugated secondary antibody for $1-2 \mathrm{~h}$, and then washed in $1 \times$ TBS-Tween for $30 \mathrm{~min}$. Ten millilitres of HRP substrate (Dupont-NEN, Boston, MA, USA) were added and incubated for $1 \mathrm{~min}$ and visualized by autoradiography. Protein band intensities were scanned on a JX-330 scanner (SHARP Corp., Mahwah, NJ, USA) using Adobe Photoshop 3.0 (Adobe Systems Inc., San Jose, CA, USA).

\section{Immunohistochemistry}

For ER $\alpha$-Sp1 colocalization experiments, MCF-7 cells were seeded onto two-well glass chamber slides (Nalge Nunc International, Naperville, IL, USA) at 100000 cells per well in Dulbecco's modified Eagle's medium (DMEM)/F12 medium supplemented with 5\% charcoal stripped FBS, incubated in a $37^{\circ} \mathrm{C}$ incubator with $5 \% \mathrm{CO}_{2}$ for $24 \mathrm{~h}$, and treated with $\mathrm{Me}_{2} \mathrm{SO}$ vehicle or $10 \mathrm{nM} \mathrm{E}_{2}$ for $1 \mathrm{~h}$. Slides were then washed with PBS, fixed with $-20^{\circ} \mathrm{C}$ methanol, air dried, and washed with PBS $+0.3 \%$ Tween 20 (PBS/Tween). Slides were blocked for $1 \mathrm{~h}$ with $5 \%$ donkey serum in antibody dilution buffer (1\% BSA in PBS/Tween), washed with PBS/Tween briefly, incubated with anti-Sp1 PEP-2 (goat) antibody (Santa Cruz) at 1:100 dilution (goat serum for controls) in antibody dilution buffer at $4{ }^{\circ} \mathrm{C}$ for $12 \mathrm{~h}$. Slides were washed with PBS/Tween $(3 \times 10 \mathrm{~min})$, incubated with donkey antigoat immunoglobulin $\mathrm{G}$ (IgG) fluorescein isothiocyanate (FITC) (Santa Cruz) at 1:200 dilution in antibody dilution buffer for $1 \mathrm{~h}$ and washed with PBS/Tween $(3 \times$ $10 \mathrm{~min}$ ). Slides were subsequently blocked with $5 \%$ donkey serum in antibody dilution buffer for $1 \mathrm{~h}$, washed with PBS/Tween briefly, incubated with anti-ER $\alpha$ H-184 antibody (Santa Cruz) at 1:100 dilution in antibody dilution buffer at $4{ }^{\circ} \mathrm{C}$ for $12 \mathrm{~h}$ (rabbit serum for controls), washed with PBS/Tween $(3 \times 10 \mathrm{~min})$, incubated with donkey anti-rabbit IgG Alexa Fluor 594 (Molecular Probes, Eugene, OR, USA) at 1:500 dilution in antibody dilution buffer for $1 \mathrm{~h}$, and washed with PBS/Tween $(3 \times 10 \mathrm{~min})$. Slides were finally washed in deionized water, and cover glass mounted using Prolong Gold antifade reagent with DAPI (Molecular Probes). Immunofluorescence images of Sp1 and $\mathrm{ER} \alpha$ were examined using a Zeiss Axioplan2 microscope (Carl Zeiss, Thornwood, NY, USA) fitted with an Axiocam highresolution digital camera. Digital images were captured using Axiovision 4.1 software (Carl Zeiss).

For ER $\alpha$-Sp4 colocalization experiments, COS-7 cells were seeded as described above, transfected with $250 \mathrm{ng}$ of ER $\alpha$ and $250 \mathrm{ng}$ of Sp4 expression plasmid using GeneJuice transfection reagent (Novagen), incubated at $37^{\circ} \mathrm{C}$ with $5 \% \quad \mathrm{CO}_{2}$ for $24 \mathrm{~h}$, and then treated with $\mathrm{Me}_{2} \mathrm{SO}$ vehicle or $10 \mathrm{nM} \mathrm{E}_{2}$ for $1 \mathrm{~h}$, and immunostaining experiments were carried out as described above using $\mathrm{ER} \alpha$ D-12 (Santa Cruz) paired with donkey anti-mouse Alexa Fluor 488 (Molecular Probes) and Sp4 V-20 (Santa Cruz) paired with donkey anti-rabbit IgG Alexa Fluor 594 (Molecular Probes) antibodies.

\section{Real-time PCR}

Cells were seeded into six-well plates in DME/F12 medium supplemented with $2.5 \%$ charcoal-stripped serum overnight. The next day cells were transfected with siRNAs using Lipofectamine 2000 Reagent and, after 55-60 h, cells were treated with $\mathrm{Me}_{2} \mathrm{SO}$ or $\mathrm{E}_{2}$ for 6 or $12 \mathrm{~h}$. RNA was extracted using Qiagen RNeasy minikit (Qiagen) following the manufacturer's protocol and was reverse transcribed for cDNA synthesis using Superscript II reverse transcriptase (Invitrogen) according to the manufacturer's protocol. The cDNA reaction mixture was then used to carry out PCR using SYBR Green PCR Master Mix from PE Applied Biosystems (Warrington, UK) on an ABI Prism 7700 Sequence Detection System (PE Applied Biosystems). The relative quantitation of samples was carried out using comparative $C_{\mathrm{T}}$ method and TATA binding protein (TBP) was used for normalization. Quantitect primer assays (Qiagen) for Sp1, Sp3, $\mathrm{Sp} 4, \mathrm{E}_{2} \mathrm{~F} 1$, and $\mathrm{CAD}$ were used to perform PCR, whereas primers for RAR $\alpha$ and TBP were purchased from Integrated DNA technologies (Coralville, IA, USA) and are as follows:

\section{RAR $\alpha($ Fwd $): 5^{\prime}$-TCC ATG CCG CCT CTC ATC-3 ${ }^{\prime}$ RAR $\alpha$ (Rev): $5^{\prime}$-CGG CTG TCC GCT CAG AGT-3' \\ TBP (Fwd): $5^{\prime}$-TGC ACA GGA GCC AAG AGT GAA-3 ${ }^{\prime}$ TBP (Rev): 5'-CAC ATC ACA GCT CCC CAC CA-3'}

\section{Chromatin immunoprecipitation (ChIP) assay}

MCF-7 cells $\left(1 \times 10^{7}\right)$ were treated with $\mathrm{Me}_{2} \mathrm{SO}$ (time 0$)$ or $\mathrm{E}_{2}(10 \mathrm{nM})$ for different times. Cells were then fixed with $1.5 \%$ formaldehyde, and the cross-linking reaction was stopped by addition of $0 \cdot 125 \mathrm{M}$ glycine. Cells were scraped, pelleted, and hypotonically lysed, and nuclei were collected. Nuclei were then sonicated to the desired chromatin length $(\sim 500 \mathrm{bp})$. The chromatin was precleared by addition of protein A/G-conjugated beads (Pierce, Rockford, IL, USA). The precleared chromatin supernatants were immunoprecipitated with antibodies specific to IgG, ER $\alpha, \mathrm{Sp} 1, \mathrm{Sp} 3$, and Sp4 (Santa Cruz Biotechnology) at $4{ }^{\circ} \mathrm{C}$ overnight. The protein-antibody complexes were collected by addition of protein A/G-conjugated beads for $1 \mathrm{~h}$, and the beads 

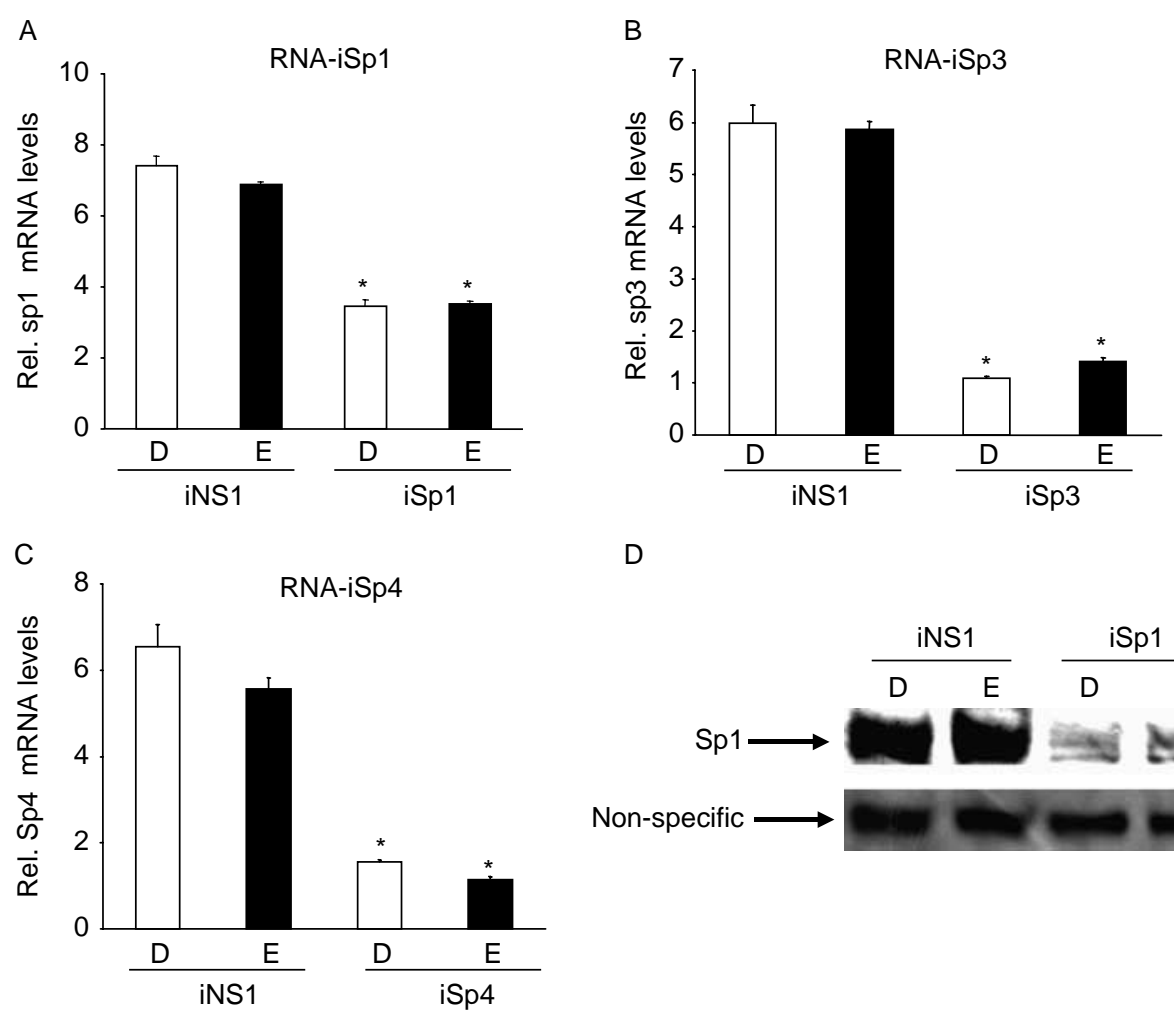

D
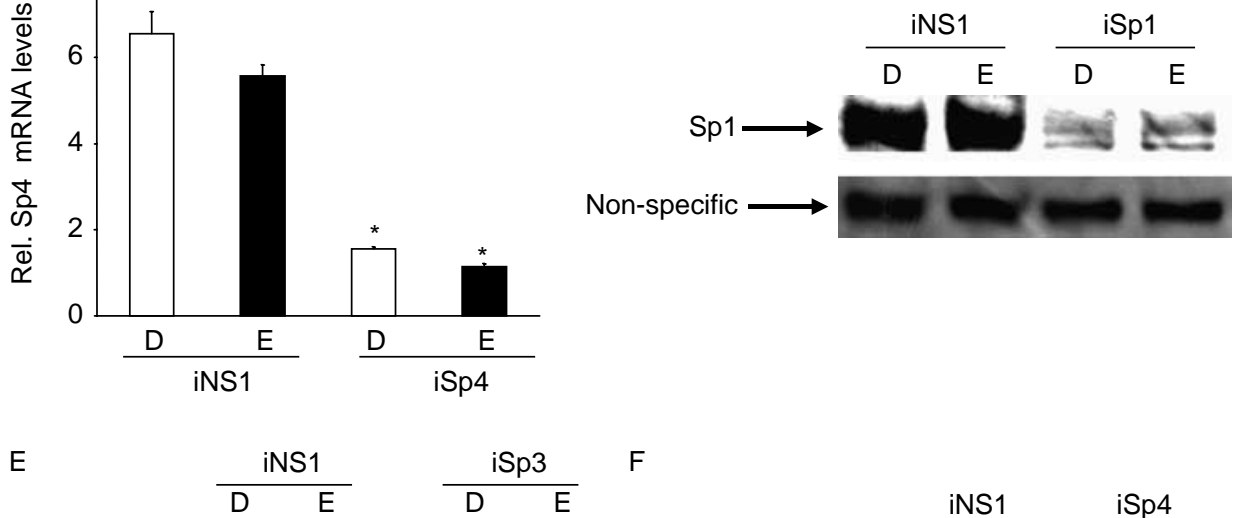

F
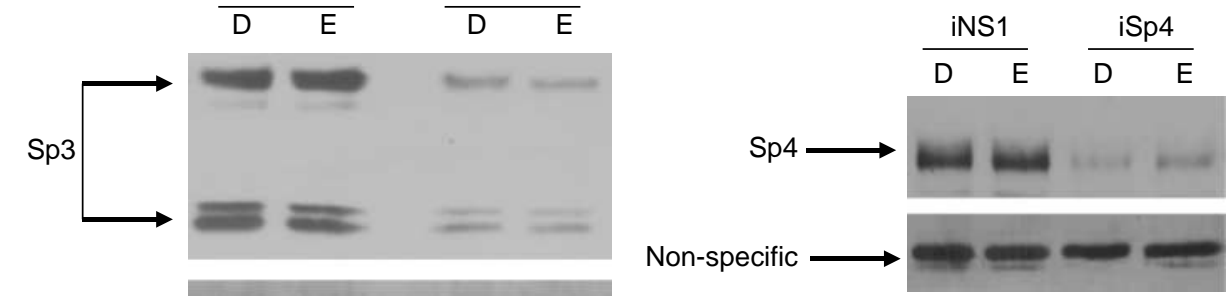

$\beta$-actin

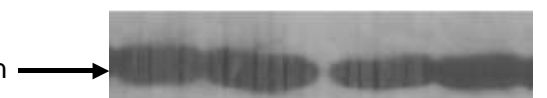

Figure 1 siRNAs for Sp1, Sp3, and Sp4. Effects of (A) iSp1, (B) iSp3, and (C) iSp4 on mRNA expression. MCF-7 cells were transfected with iNS1, iSp1, iSp3, or iSp4, treated with $\mathrm{Me}_{2} \mathrm{SO}$ (D), $10 \mathrm{nM} \mathrm{E}_{2}(\mathrm{E})$, and Sp mRNA levels were determined by real-time PCR as described in the Materials and methods. Results are expressed as means \pm S.E.M. for three replicated determinations for each treatment group. Significantly $(P<0.05)$ decreased mRNA levels by iSps is indicated by an asterisk. Effects of (D) iSp1, (E) iSp3, and (F) iSp4 on protein expression. MCF-7 cells were transfected with siRNAs as described above, treated with $\mathrm{Me}_{2} \mathrm{SO}(\mathrm{D})$ or $10 \mathrm{nM} \mathrm{E}_{2}(\mathrm{E})$ and whole cell lysates were analyzed by western blot analysis as described in Materials and methods.

were extensively washed. The protein-DNA crosslinks were eluted and reversed. DNA was purified by Qiaquick Spin Columns (Qiagen) followed by PCR amplification. The pS2 primers are: 5'-CTA GAC GGA ATG GGC TTC AT- $3^{\prime}$ (forward) and $5^{\prime}$-ATG GGA GTC TCC TCG AAC CT-3' (reverse), which amplify a 209-bp region of the human pS2 promoter containing an estrogen response element (ERE). The CAD primers are: $5^{\prime}$-CTT GGG GTG GGA GGG ACT-3' (forward) and 5'-GCG GCA GCA
GCA GAG ACT-3' (reverse), which amplify a 158-bp GC-rich region of the human CAD promoter. The RAR $\alpha$ primers are: $5^{\prime}$-GCC CTT CCC GAG GTC TAT TA- $3^{\prime}$ (forward) and 5'-GAG GGT ACG GAG CAG AGG TA-3' (reverse), which amplify a 138-bp GC-rich region of the human RAR $\alpha$ promoter. The $\mathrm{E}_{2} \mathrm{~F} 1$ primers are: $5^{\prime}$-CTG gta cca tcc gga caa ag-3' (forward) and $5^{\prime}$-TTT TTG CCG CGA AAG AGC-3' (reverse), which amplify a 198-bp region of the human $\mathrm{E}_{2} \mathrm{~F} 1$ promoter containing GC-rich 


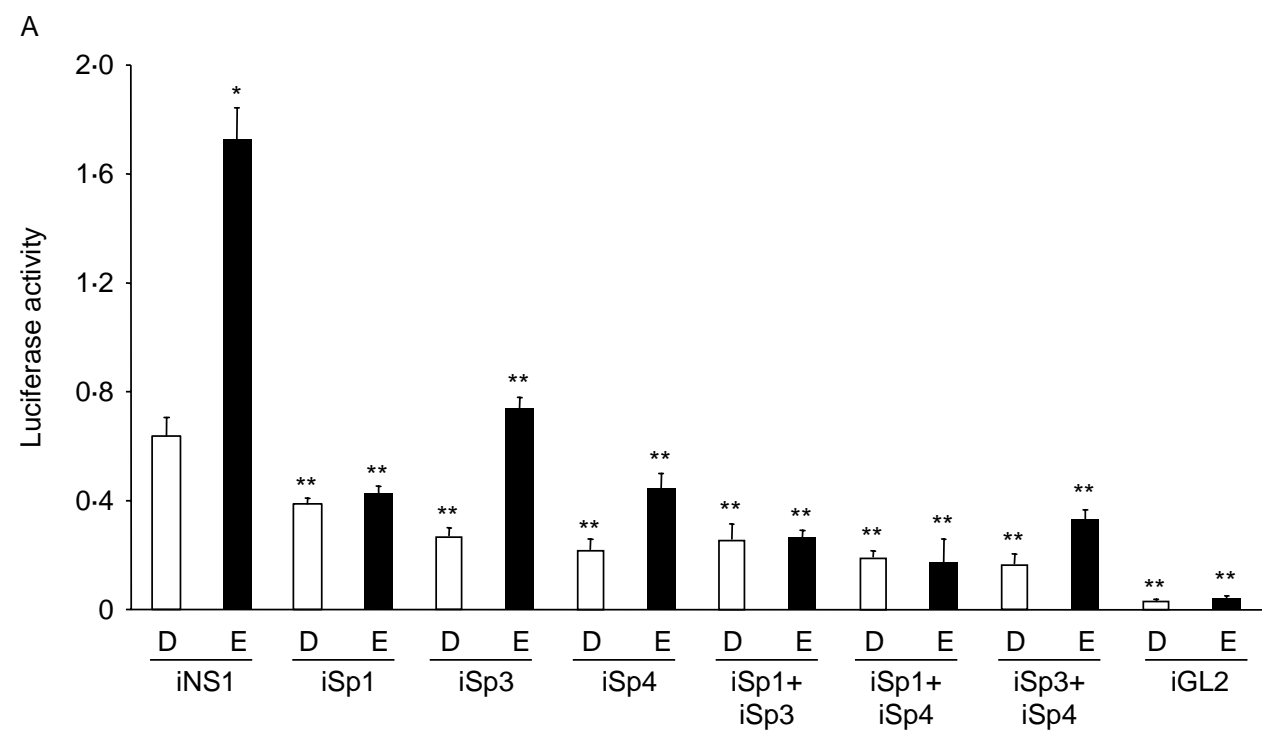

B

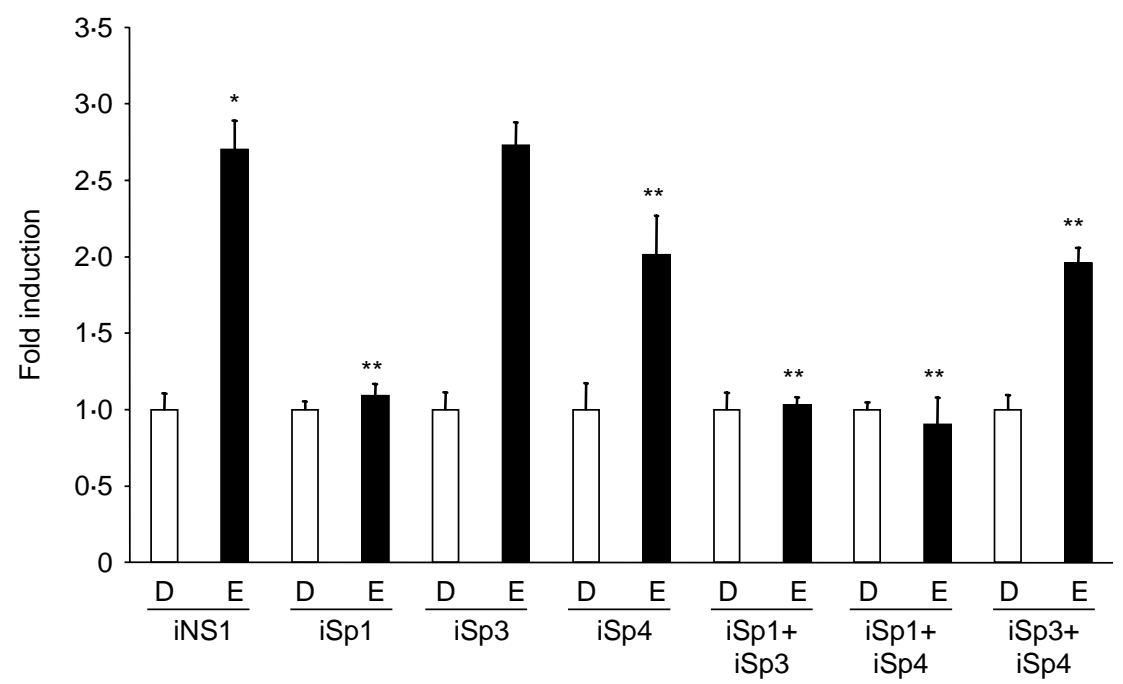

Figure 2 Role of Sp proteins in hormonal activation of $p S p 1_{3}$. MCF-7 cells were cotransfected with $p S p 1_{3}$ and iNS1, iSp1, iSp3, iSp4, or their combinations, treated with $\mathrm{Me}_{2} \mathrm{SO}(\mathrm{D})$ or $10 \mathrm{nME}_{2}(\mathrm{E})$, and (A) luciferase activity or $(B)$ fold induction of luciferase activity by $E_{2}$ was determined as described in the Materials and methods. Results are expressed as means \pm S.E.M. for at least three replicate determinations for each treatment group, and significantly $(P<0.05)$ decreased basal or $\mathrm{E}_{2}$-induced activity (compared with iNS1) is indicated by a double asterisk. Significant $(P<0 \cdot 05)$ induction by $\mathrm{E}_{2}$ compared with $\mathrm{Me}_{2} \mathrm{SO}$ is also indicated (*).

Sp-binding sites. PCR products were resolved on a $2 \%$ agarose gel in the presence of 1:10000 SYBR gold (Molecular Probes).

\section{Statistical analysis}

Experiments were repeated two or more times, and data are expressed as mean \pm s.E.M. for at least three replicates for each treatment group. Statistical differences between treatment groups were determined using Super ANOVA and Scheffé's test. Treatments were considered significantly different from controls if $P<0 \cdot 05$.

\section{Results}

\section{Role of Sp proteins of hormonal activation of $\mathrm{pSp}_{3}$}

Analysis of several gene promoters from $\mathrm{E}_{2}$-responsive genes have identified GC-rich motifs that are required 


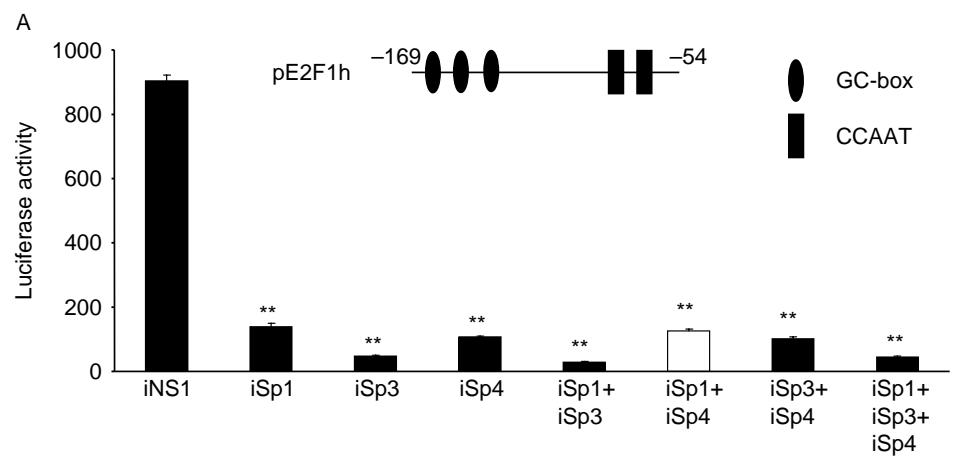

B
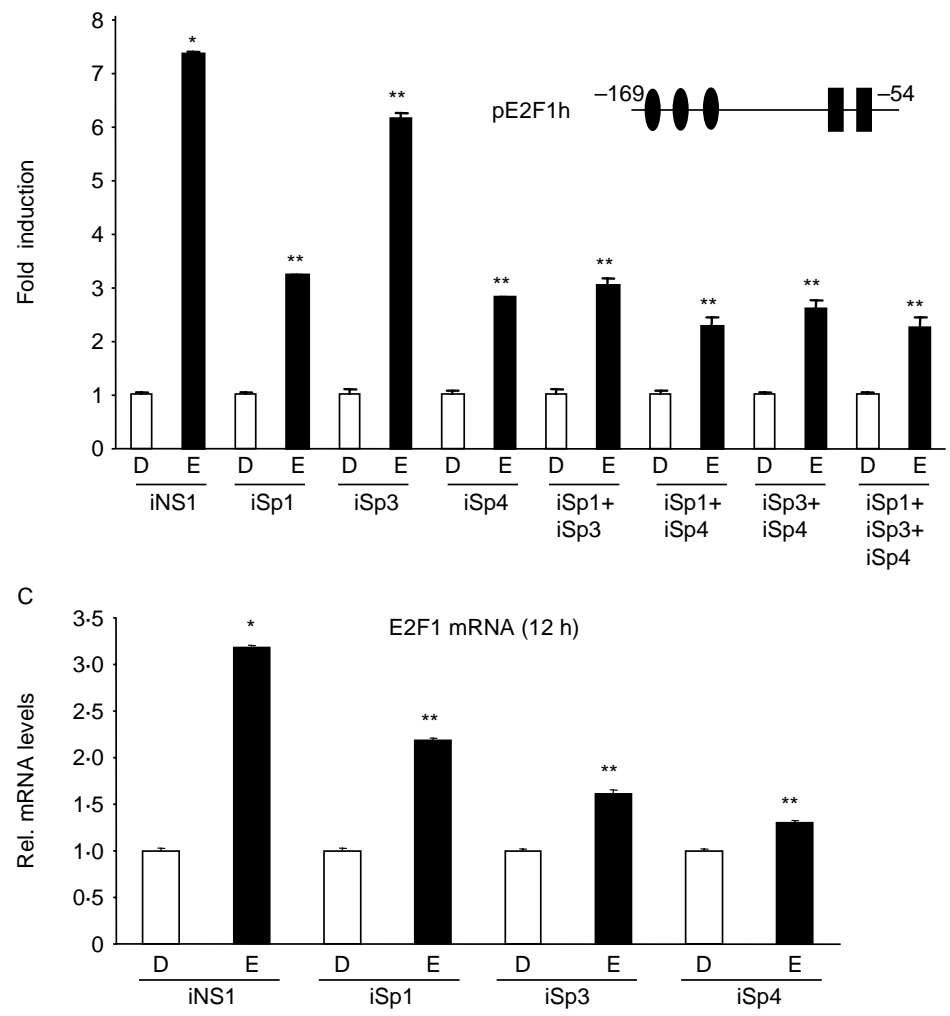

D

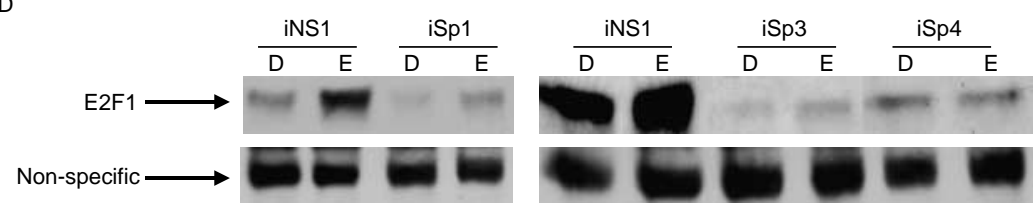

Figure 3 Role of $S p$ proteins in hormonal activation of $E_{2} F 1$. (A) Luciferase activity and (B) fold induction by $E_{2}$ in MCF-7 cells cotransfected with $\mathrm{ER} \alpha$ expression plasmid $(150 \mathrm{ng})$ and $\mathrm{pE}_{2} \mathrm{~F} 1(-161 /+54)$. MCF-7 cells were transfected with $\mathrm{pE} \mathrm{E}_{2} \mathrm{~F} 1(-161 /+54)$ and iNS1, iSp1, iSp3, iSp4, or their combinations, and luciferase activity determined as described in the Materials and methods. Hormonal activation of $\mathrm{pE}_{2} \mathrm{~F} 1$ requires cotransfection with $\mathrm{ER} \alpha$. Results are expressed as means \pm s.E.M. for three replicate determinations for each treatment group, and significantly $(P<0.05)$ decreased basal or hormone-induced activity (compared with iNS1) is indicated $\left({ }^{\star \star}\right)$. Role of Sp proteins in hormonal activation of $(C) E_{2} F 1$ mRNA and (D) protein. Cells were transfected with iNS1, iSp1, iSp3, or iSp4, and then treated with $\mathrm{Me}_{2} \mathrm{SO}$ (D) or $10 \mathrm{nM} \mathrm{E} \mathrm{E}_{2}(\mathrm{E})$ for $12 \mathrm{~h}$. Whole cell extracts were analyzed for $\mathrm{E}_{2} \mathrm{~F} 1$ mRNA or protein as described in the Materials and methods. $\mathrm{E}_{2} \mathrm{~F} 1 \mathrm{mRNA}$ data were determined in three separate experiments and results (normalized to TBP mRNA) are means \pm s.E.M.. Significant $(P<0.05)$ inhibition of $E_{2}$-induced mRNA levels by iSp1, iSp2, and iSp3 are indicated $\left(^{* *}\right)$. Western blot analysis of whole cell lysates was determined as described in the Materials and methods. The immunoblot shown in Fig. $3 \mathrm{D}$ was one of two replicates that gave similar results. Significant induction by $\mathrm{E}_{2}$ compared with $\mathrm{Me}_{2} \mathrm{SO}$ (D) is indicated $\left(^{*}\right)$. 
for hormone-induced transactivation in breast cancer and other cell lines (Porter et al. 1996, 1997, Duan et al. 1998, Sun et al. 1998, 2005, Dong et al. 1999, Qin et al. 1999, Wang et al. 1999, 2002, Xie et al. 1999, 2000, Byrne et al. 2000, Salvatori et al. 2000, Saville et al. 2000, Stoner et al. 2000, 2004, Tanaka et al. 2000, Castro-Rivera et al. 2001, Li et al. 2001, Samudio et al. 2001, Bruning et al. 2003, Jacobson et al. 2003, Khan et al. 2003, Ngwenya \& Safe 2003, Schultz et al. 2003, 2005, Fujita et al. 2004, Bardin et al. 2005, Zhao et al. 2005, Higgins et al. 2006b). In this study, we have also used RNA interference and small inhibitory RNAs (siRNAs) for Sp1 (iSp1), Sp3 (iSp3), and Sp4 (iSp4) to investigate the role of individual Sp proteins in ER $\alpha /$ Sp-mediated transactivation in MCF-7 cells. Previous studies in cancer cell lines have demonstrated the specificity and effectiveness of iSp1, iSp3, and iSp4 in Sp protein knockdown (Abdelrahim et al. 2002, 2004, Higgins et al. 2006a,b), and results in Fig. 1A-C illustrate that transfected iSp1, iSp3, and iSp4 significantly decreased Sp1, Sp3, and Sp4 mRNA levels in whole cell extracts from MCF-7 cells. In parallel studies, transfected iSp1, iSp3, and iSp4 also decreased Sp1, Sp3, and Sp4 protein expression (Fig. 1D-F) in MCF-7 cells.

The $\mathrm{pSpl}_{3}$ construct has been extensively used as a model to investigate the mechanisms of $\mathrm{ER} \alpha / \mathrm{Sp}-$ mediated transactivation (Saville et al. 2000, Kim et al. 2003, 2005). This construct contains three tandem consensus GC-rich binding sites linked to a minimal TATA-luciferase and is $\mathrm{E}_{2}$ responsive only after cotransfection with $\mathrm{ER} \alpha$ and this is due, in part, to overexpression of $\mathrm{pSp}_{3}$ in transfected cells and limiting levels of ER $\alpha$. This system has been ideal for studying hormone activation of $\mathrm{pSp}_{3}$ in ER-positive or ER-negative cell lines thereby determining the contributions of cell context on the induction response (Saville et al. 2000, Kim et al. 2003, 2005). Results illustrated in Fig. 2A show that $\mathrm{E}_{2}$ induces transactivation in MCF-7 cells transfected with $\mathrm{pSp}_{3}$ and non-specific RNA (iNS1) and similar results were obtained in the presence or absence of transfected iNS1 oligonucleotide (data not shown). The results show that all three siRNAs or their combinations significantly decreased basal luciferase activity, and iSp1 and iSp4 were more effective than iSp3. The fold induction of luciferase by $\mathrm{E}_{2}$ compared with solvent $\left(\mathrm{Me}_{2} \mathrm{SO}\right)$ control shows that the effectiveness of the siRNAs for decreasing fold induction was iSp1 $>$ iSp4 $>$ iSp3 (Fig. 2B) with only minimal changes in fold induction observed for iSp4 and iSp3. The apparent lack of effectiveness of iSp4 and iSp3 for inhibiting fold induction of luciferase activity when compared with iSp1 was due, in part, to their differential inhibitory effects on basal luciferase activity. In cells transfected with iSps in combination, the maximal inhibition of fold induction was observed in cells transfected with iSp1/iSp3 and iSp1/iSp4, whereas minimal changes were observed in cells transfected with iSp3/iSp4. However, these data suggest that for the $\mathrm{pSp}_{3}$ construct containing three consensus GC-rich sites, Sp1 plays the most important role in $\mathrm{E}_{2}$-dependent activation of $\mathrm{ER} \alpha / \mathrm{Sp}$.

\section{$E R \alpha / S p$-mediated activation of $E_{2} F 1$}

$\mathrm{E}_{2}$ induces $\mathrm{E}_{2} \mathrm{~F} 1$ gene expression in MCF-7 cells (Wang et al. 1999, Ngwenya \& Safe 2003), and promoter analysis has identified critical GC-rich sites at between -169 and -111 in the proximal region of the $\mathrm{E}_{2} \mathrm{~F} 1$ promoter. Figure 3A illustrates luciferase activity in MCF-7 cells transfected with $\mathrm{pE}_{2} \mathrm{~F} 1(-169 /-54)$ and various iSps or their combinations. The results show that individual siRNAs for Sp1, Sp3, and Sp4 decreased luciferase by $70-90 \%$ with iSp3 as the most effective siRNA. These results indicate that $\mathrm{Sp}$ proteins play the major role in regulating basal luciferase activity in MCF-7 cells transfected with $\mathrm{pE}_{2} \mathrm{~F} 1(-169 /-54)$. Moreover, the effectiveness of iSp1, iSp3, and iSp4 in decreasing activity suggests that the loss of any single $\mathrm{Sp}$ protein was important for transcription, indicating cooperative interactions among these transcription factors for regulating luciferase activity. The effects of individual and combined Sp protein knockdown in MCF-7 cells transfected with $\mathrm{pE}_{2} \mathrm{~F} 1(-169 /-54)$ and treated with $\mathrm{Me}_{2} \mathrm{SO}$ or $\mathrm{E}_{2}$ were also determined, and the effects on fold induction by $\mathrm{E}_{2}$ are illustrated in Fig. 3B. With the exception of the results observed for iSp3, the fold induction by $\mathrm{E}_{2}$ was decreased $50-65 \%$ by iSp1, iSp4, and their combinations (including iSp3+iSp1 and iSp3+iSp4). iSp3 only slightly decreased the fold induction by $\mathrm{E}_{2}$ and was less effective than either iSp1 or iSp4. These results were similar to those observed for the effects of iSps on hormone inducibility in MCF-7 cells transfected with $\mathrm{pSp}_{3}$ (Fig. 2A).

The effects of siRNAs for Sp proteins on induction of $\mathrm{E}_{2} \mathrm{~F} 1 \mathrm{mRNA}$ levels in MCF-7 cells were also investigated. Cells were transfected with iNS1 (non-specific RNA), iSp1, iSp3 or iSp4 for 55-60 h, then treated with $\mathrm{Me}_{2} \mathrm{SO}$

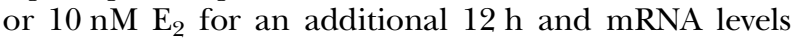
were determined in whole cell extracts by real-time PCR. Previous studies show that within this time period, there is a maximal decrease of $\mathrm{Sp}$ proteins using these siRNAs (Abdelrahim et al. 2002, 2004, Higgins et al. 2006a,b). Basal $\mathrm{E}_{2} \mathrm{~F} 1 \mathrm{mRNA}$ levels were significantly decreased by transfecting iSp1, iSp3, and iSp4 by 40,86 , and $77 \%$ respectively, demonstrating the role of $\mathrm{Sp}$ proteins in mediating $\mathrm{E}_{2} \mathrm{~F} 1 \mathrm{mRNA}$ expression. $\mathrm{E}_{2}$ induced an approximately threefold increase in $\mathrm{E}_{2} \mathrm{~F} 1 \mathrm{mRNA}$ expression and in cells transfected with iSp1, iSp3, and iSp4, there were significant decreases in hormoneinduced $\mathrm{E}_{2} \mathrm{~F} 1 \mathrm{mRNA}$ levels and cells transfected with iSp4 gave the lowest inducibility. However, the results suggest that all three Sp proteins are involved in ER $\alpha$ / Sp-dependent activation of $\mathrm{E}_{2} \mathrm{~F} 1$. iSp3 was more effective in decreasing induction of $\mathrm{E}_{2} \mathrm{~F} 1 \mathrm{mRNA}$ by $\mathrm{E}_{2}$ (Fig. 3C) 

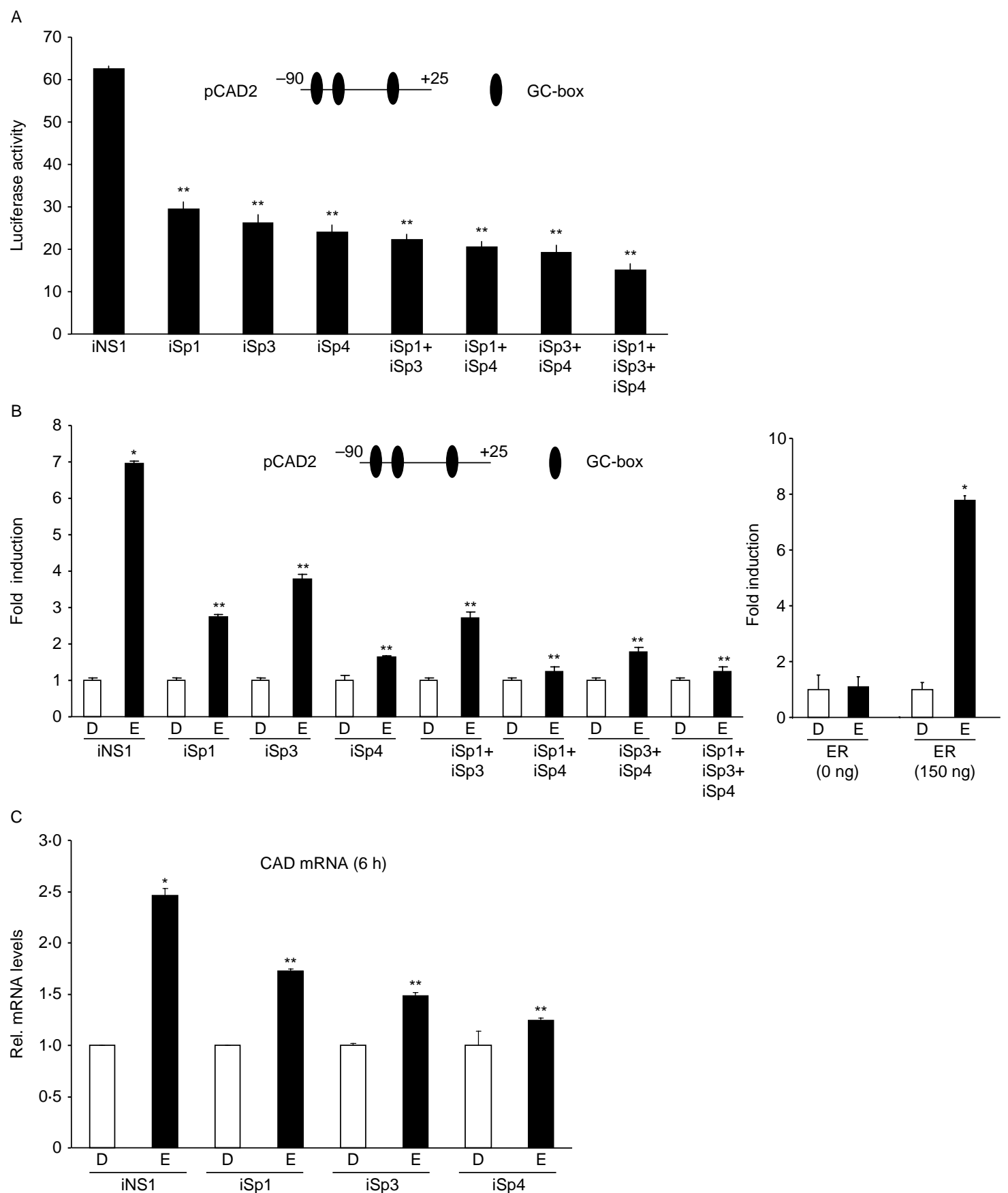

Figure 4 Role of $\mathrm{Sp}$ proteins in hormonal activation of CAD. (A) Luciferase activity and (B) fold induction by $E_{2}$ in MCF-7 cells cotransfected with ER $\alpha$ expression plasmid $(150 \mathrm{ng})$ and PCAD $(-90 /+25)$. MCF-7 cells were transfected with pCAD $(-90 /+25)$ and iNS1, iSp1, iSp3, iSp4, or their combinations, and luciferase activity determined as described in the Materials and methods. The requirement of $E R \alpha$ for hormonal activation of this construct is also indicated (B). Results are expressed as means \pm S.E.M. for three replicate determinations for each treatment group, and significantly $(P<0.05)$ decreased basal or hormone-induced activity (compared with iNS1) is indicated ( $\left.{ }^{* *}\right)$. The effects of ER expression plasmid on hormone inducibility is also indicated. (C) Role of Sp proteins in hormonal activation of CAD mRNA. MCF-7 cells were transfected with iNS, iSp1, iSp3, or iSp4, treated with Me $\mathrm{e}_{2} \mathrm{SO}$ (D) or $10 \mathrm{nM} \mathrm{E}_{2}(\mathrm{E})$ for $6 \mathrm{~h}$, and mRNA levels determined as described in the Materials and methods. CAD mRNA levels (normalized to TBP mRNA) are means \pm S.E.M. for at least three determinations and significantly $(P<0.05)$ decreased hormone-induced CAD mRNA is indicated (**). Significant induction by $\mathrm{E}_{2}$ compared with $\mathrm{ME}_{2} \mathrm{SO}$ is indicated $\left(^{*}\right)$. 
than decreasing induction of luciferase activity by $\mathrm{E}_{2}$ in cells transfected with $\mathrm{pE}_{2} \mathrm{~F} 1 \mathrm{~h}$ (Fig. $3 \mathrm{~B}$ ). This suggests that other regulatory regions of $\mathrm{E}_{2} \mathrm{~F} 1$ that are affected by Sp3 are important for induction of $\mathrm{E}_{2} \mathrm{~F} 1 \mathrm{mRNA}$ levels by $\mathrm{E}_{2}$. We also observed in a separate experiment that induction of $\mathrm{E}_{2} \mathrm{~F} 1$ protein by $\mathrm{E}_{2}$ and basal $\mathrm{E}_{2} \mathrm{~F} 1$ protein expression were also decreased in MCF-7 cells transfected with iSp1, iSp3, and iSp4 (Fig. 3D). These results demonstrate the hormone inducibility of $\mathrm{E}_{2} \mathrm{~F} 1$ is dependent on Sp transcription factors. Thus, although Sp3 plays a minimal role in hormone-induced activation of $\mathrm{pE}_{2} \mathrm{~F} 1(-169 /-54)$, this transcription factor is important for mediating hormone-dependent induction of $\mathrm{E}_{2} \mathrm{~F} 1 \mathrm{mRNA}$ and protein.

\section{ER $\alpha / S p$-mediated activation of CAD and RAR $\alpha$}

The -90 to +25 region of the $\mathrm{CAD}$ gene promoter is also $\mathrm{E}_{2}$ responsive in transfection assays, and deletion and mutation analyses have identified three proximal GC-rich sites which are required for hormone responsiveness (Khan et al. 2003). Results in Fig. 4A show that in MCF-7 cells transfected with pCAD $(-90 /+25)$, cotransfection with iSp1, iSp3, iSp4, or their combinations significantly decreased activity $(>50 \%)$; however, the magnitude of the decreased activity was significantly less than observed for $\mathrm{pE}_{2} \mathrm{~F} 1$ ( $-169 /-54$; Fig. 3A). Since the magnitude of the decreased response was similar after transfection with iSp1, iSp3, or iSp4, it is likely that all three transcription factors are required for basal activity. In MCF-7 cells transfected with pCAD $(-90 /+25)$ plus iNS1 and treated with $\mathrm{Me}_{2} \mathrm{SO}$ or $\mathrm{E}_{2}$, cotransfection with iSp1, iSp3, iSp4, or their combinations significantly decreased hormone-induced transactivation (Fig. 4B). Fold induction was decreased only slightly more effectively in cells transfected with iSpl and iSp4 when compared with iSp3; however, all three $\mathrm{Sp}$ transcription factors were important for hormone responsiveness and combinations of iSps inhibited hormone inducibility more than individual siRNAs. Similar results were observed for induction of $\mathrm{CAD} m \mathrm{mRN}$ levels by $\mathrm{E}_{2}$ (Fig. $4 \mathrm{C}$ ) where the induction response was significantly decreased in MCF-7 cells transfected with iSp1, iSp3, and iSp4. In contrast, iSps had only a minimal effect of CAD mRNA levels (data not shown).

We also investigated the role of Sp proteins in hormonal activation of $\operatorname{RAR} \alpha$ since previous studies have identified proximal GC-rich motifs at -68 to -62 and -59 to -52 required for hormonal activation of promoter constructs (Sun et al. 1998). In contrast to the pCAD $(-90 /+25)$ and $\mathrm{pE}_{2} \mathrm{~F} 1(-169 /-54)$ constructs, basal luciferase activity was not decreased in MCF-7 cells transfected with $\mathrm{pRAR} \alpha(-79 /-49)$ and iSp1 or iSp4 but was significantly decreased only after cotransfection with iSp3 (Fig. 5A). Cotransfection with iSp combinations (except iSp1+iSp3) decreased activity; however, it was evident that despite the presence of GC-rich motifs in pRAR $\alpha(-79 /-49)$, Sp proteins were not the predominant transcription factors required for basal activity. In contrast, fold inducibility of luciferase activity in MCF-7 cells treated with $\mathrm{Me}_{2} \mathrm{SO}$ or $10 \mathrm{nME}_{2}$ and transfected with $\operatorname{pRAR} \alpha(-79 /-49)$ was primarily decreased in cells transfected with iSp1 and iSp4 but not iSp3 (Fig. 5B). Since both iSp1 and iSp4 significantly decreased hormone responsiveness, any combination of these siRNAs inhibited $\mathrm{E}_{2}$-induced transactivation. Thus, hormone-dependent activation of $\operatorname{pRAR} \alpha(-79 /-49)$ was primarily dependent on $\mathrm{ER} \alpha / \mathrm{Sp} 1$ and $\mathrm{ER} \alpha / \mathrm{Sp} 4$, and this was similar to results obtained with $\mathrm{pSpl}_{3}$ (Fig. 2B) and $\mathrm{pE}_{2} \mathrm{~F} 1$ ( $-169 /-54$; Fig. 3B). Basal expression of RAR $\alpha$ mRNA was only minimally affected by iSps (data not shown); however, induction of RAR $\alpha$ mRNA levels by $\mathrm{E}_{2}$ was decreased after cotransfection with iSp1, iSp3, and iSp4 with iSp3 being the most effective siRNA (Fig. 5C). iSp3 completely abrogated induction of RAR $\alpha$ by $\mathrm{E}_{2}$, whereas in transfection studies with pRAR $\alpha 2$, which contains a -79 to -49 RAR $\alpha$ promoter insert, iSp3 did not significantly decrease hormone responsiveness (Fig. 5B). These results suggest that GC-rich sites in addition to those at -79 to -49 may be important for $\mathrm{ER} \alpha /$ Sp-mediated induction of RAR $\alpha$ mRNA by $\mathrm{E}_{2}$.

\section{Colocalization of ER $\alpha$ with Sp1 and Sp4}

Previous studies showed that ER $\alpha$ interacts with Sp1 and Sp3 (Porter et al. 1996, 1997, Saville et al. 2000, Stoner et al. 2000); however, the results of RNA interference assays now demonstrate that, in MCF-7 cells, Sp4 plays an important role in $\mathrm{E}_{2}$-dependent activation of $\mathrm{ER} \alpha / \mathrm{Sp}$. Therefore, we have investigated colocalization of ER $\alpha$ and Sp1 in MCF-7 cells, which exhibit endogenous expression of both proteins (Fig. 6A). ER $\alpha$ and Sp1 proteins alone exhibit nuclear staining and the colocalized proteins exhibit a punctate staining pattern, and these results complement previous studies showing direct interactions of both proteins (Porter et al. 1997). Colocalization experiments with $\mathrm{ER} \alpha$ and Sp4 were examined in COS-7 cells transfected with $\mathrm{ER} \alpha$ and $\mathrm{Sp} 4$ expression plasmids (Fig. 6B). Immunostaining of endogenous Sp4 in MCF-7 cells was weak due to the relative insensitivity of the commercially available antibodies; however, in transfected COS-7 cells, Sp4 staining is observed and is more intense in the central part of the nucleus. ER $\alpha$ alone is uniformally observed in the nucleus and, after treatment with $\mathrm{E}_{2}$, a more punctate staining is observed and the colocalized $\mathrm{ER} \alpha / \mathrm{Sp} 4$ also exhibited punctate staining. Several attempts to investigate colocalization of ER $\alpha$ and Sp3 were unsuccessful, due to the failure of available Sp3 antibodies to detect Sp3 by this method. However, these results demonstrate that $\mathrm{ER} \alpha$ colocalizes with Sp1 and $\mathrm{Sp} 4$ and these transcription factors play an important role in $\mathrm{ER} \alpha / \mathrm{Sp}$-mediated expression of $\mathrm{E}_{2} \mathrm{~F} 1, \mathrm{CAD}$, and $\mathrm{RAR} \alpha$ 

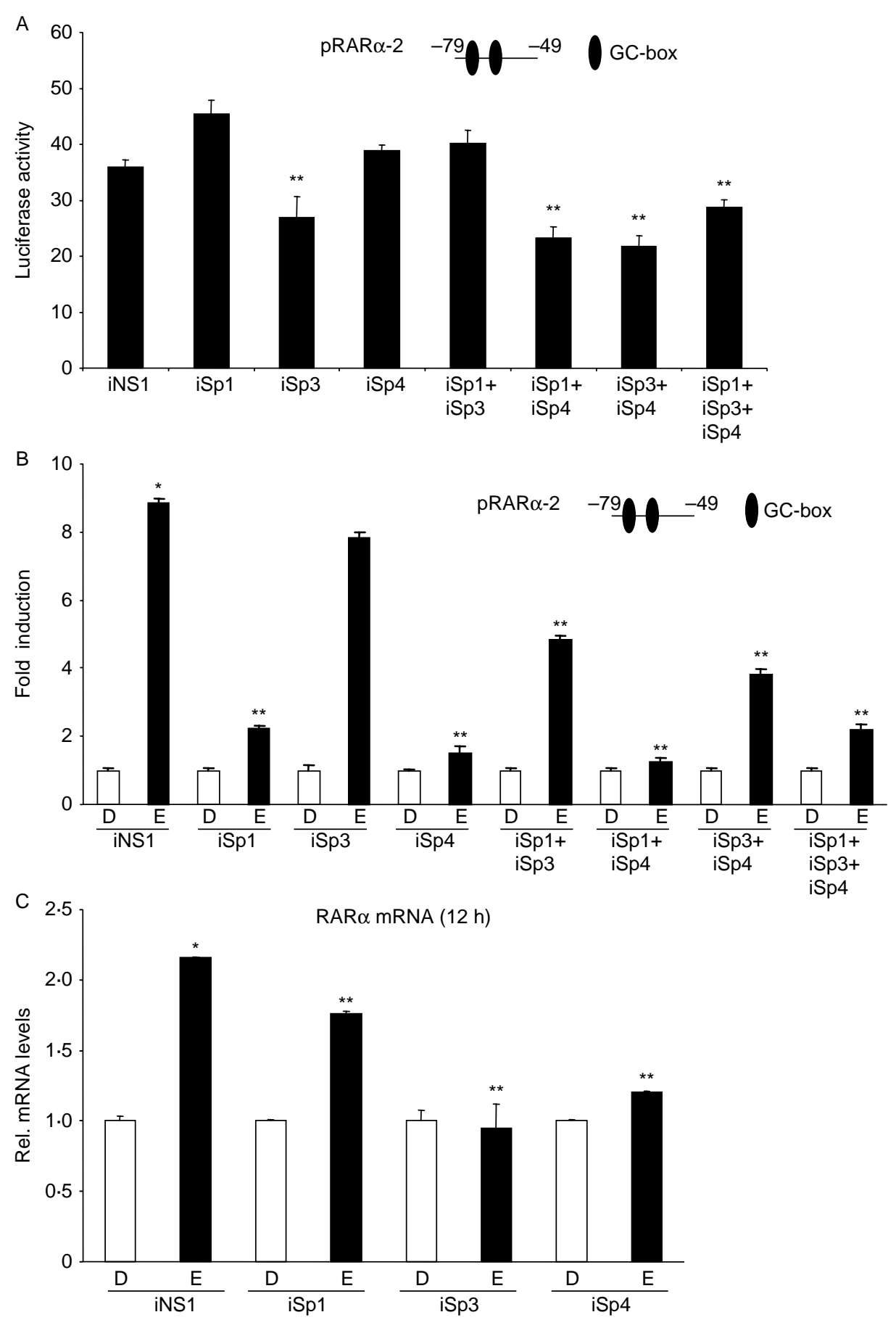

Figure 5 Role of $\mathrm{Sp}$ proteins in hormonal activation of RAR $\alpha$. (A) Luciferase activity and (B) fold induction by $E_{2}$ in MCF-7 cells cotransfected with $\mathrm{ER} \alpha$ expression plasmid $(150 \mathrm{ng})$ and $\mathrm{pRAR} \alpha(-79 /-49)$. MCF-7 cells were transfected with pRAR $\alpha(-79 /-49)$ and iNS1, iSp1, iSp3, iSp4, or their combinations, and luciferase activity determined as described in the Materials and methods. Hormonal activation of $\mathrm{pRAR} \alpha$ requires cotransfection with $\mathrm{ER} \alpha$. Results are expressed as means \pm s.E.M. for three replicate determinations for each treatment group, and significantly $(P<0.05)$ decreased basal or hormone-induced activity (compared with iNS1) is indicated $\left.{ }^{* *}\right)$. (C) Role of Sp proteins in hormonal activation of RAR $\alpha$ mRNA. MCF-7 cells were transfected with iNS, iSp1, iSp3, or iSp4, treated with $\mathrm{Me}_{2} \mathrm{SO}$ (D) or $10 \mathrm{nM} \mathrm{E} \mathrm{E}_{2}(\mathrm{E})$ for $12 \mathrm{~h}$, and mRNA levels determined as described in the Materials and methods. RAR $\alpha$ mRNA levels (normalized to TBP mRNA) are expressed as means \pm s.E.M. for at least three determinations and significantly $(P<0.05)$ decreased induction (fold) of RAR $\alpha$ mRNA by $E_{2}$ is indicated $\left(^{* *}\right)$. Significant induction by $E_{2}$ compared with $\mathrm{ME}_{2} \mathrm{SO}$ is indicated $\left(^{*}\right)$. 

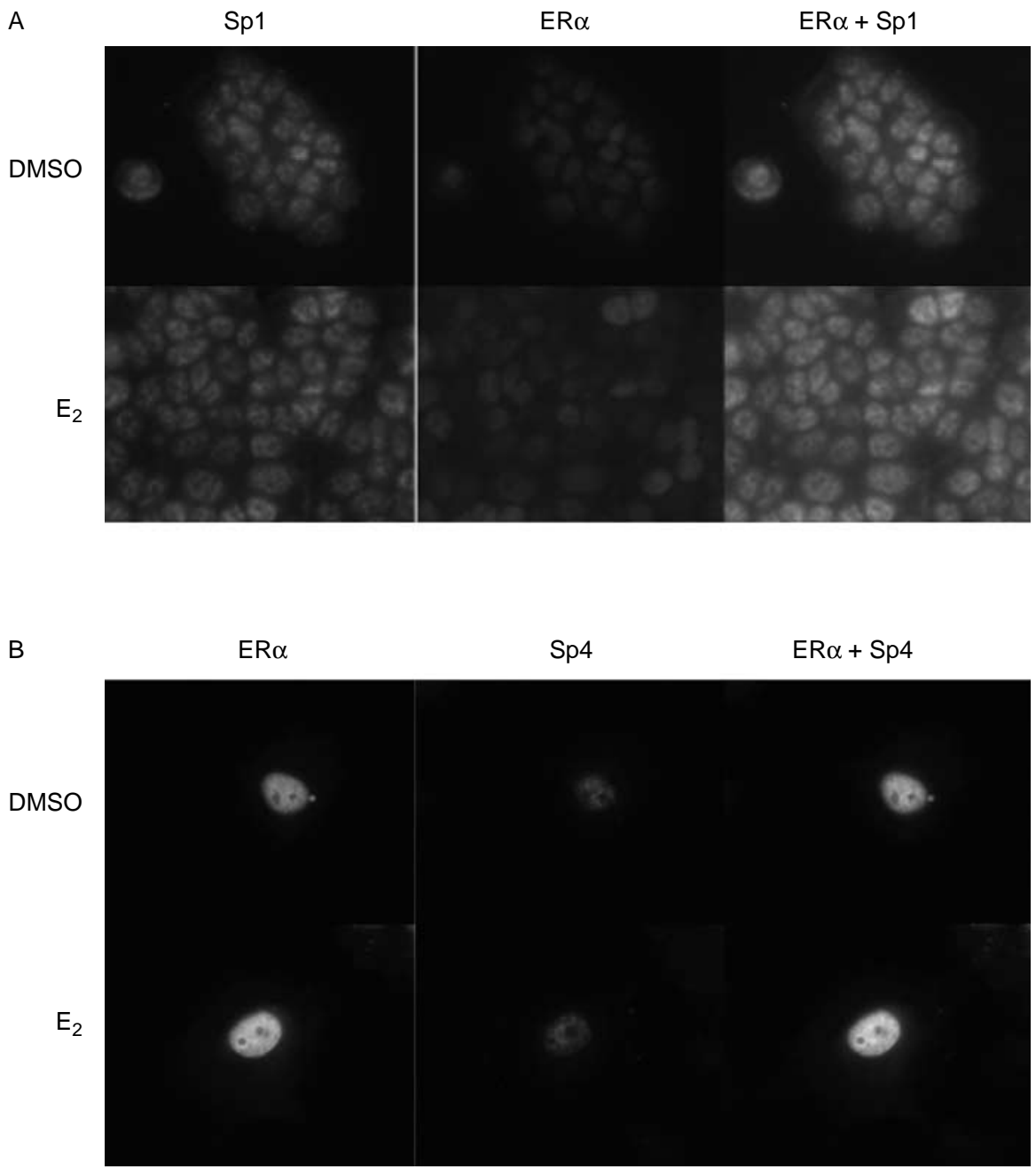

Figure 6 Colocalization of ER $\alpha$ with Sp1 and Sp4 in (A) MCF-7 and (B) COS-7 cells. MCF-7 and COS-7 cells were seeded in two-well chamber slides. The latter cells were transfected with ER $\alpha$ and Sp4 expression plasmids. Both cell lines were treated with $\mathrm{Me}_{2} \mathrm{SO}$ or $10 \mathrm{nM} \mathrm{E}_{2}$ for $1 \mathrm{~h}$, and cells were immunostained as described in the Materials and methods.

in MCF-7 cells. However, the effects of $\mathrm{E}_{2}$ on colocalization are minimal, suggesting interactions of $\mathrm{ER} \alpha$ with $\mathrm{Sp}$ proteins in the presence or absence of hormone, and this is consistent with previous ChIP assays (Higgins et al. $2006 a)$ and the reported coimmunoprecipitation of $\mathrm{ER} \alpha$ and Sp1 ( \pm hormone; Saville et al. 2000).

\section{Interactions of $E R \alpha$ and $S p$ proteins with the $p S 2, E_{2} F 1$, CAD, and RAR $\alpha$ gene promoters}

Previous studies show that the $\mathrm{E}_{2}$-responsive region of the pS2 gene promoter contains GC-rich motifs and ChIP analysis of the pS2 promoter (Fig. 7A) shows constitutive binding of Sp1, Sp3, and Sp4. The band intensities exhibit minimal changes after treatment with $10 \mathrm{nM} \mathrm{E}_{2}$ for up to
$2 \mathrm{~h}$. However, as previously reported (Shao et al. 2002, Metivier et al. 2003, Acevedo et al. 2004, Krieg et al. 2004, Sun et al. 2005), treatment of MCF-7 cells recruits ER $\alpha$ to the $\mathrm{pS} 2$ promoter, and this is consistent with interactions with the ERE motif at -405 to -393 . Results in Fig. 7B-D summarize ChIP assays, which examine basal and hormone-induced interactions of $\mathrm{ER} \alpha, \mathrm{Sp} 1, \mathrm{Sp} 3$, and $\mathrm{Sp} 4$ with the GC-rich regions of the RAR $\alpha, \mathrm{E}_{2} \mathrm{~F} 1$, and $\mathrm{CAD}$ gene promoters respectively. Sp1, Sp3, and Sp4 are constitutively bound to all three promoters and treatment with $\mathrm{E}_{2}$ does not increase or decrease Sp interactions with these promoters. Moreover, similar results were also observed for ER $\alpha$ which was bound to the GC-rich RAR $\alpha$, $\mathrm{E}_{2} \mathrm{~F} 1$, and $\mathrm{CAD}$ gene promoters in the presence or absence of hormone treatment. Since Sp1, Sp3, and Sp4 
pS2 promoter
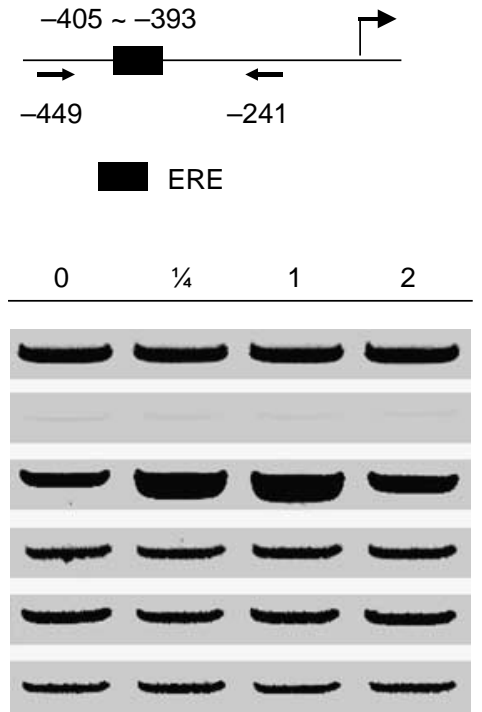

C E2F1 promoter
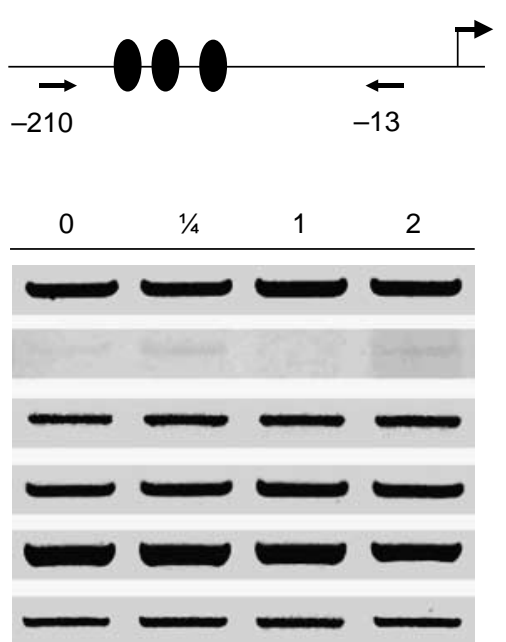

B

$R A R \alpha$ promoter
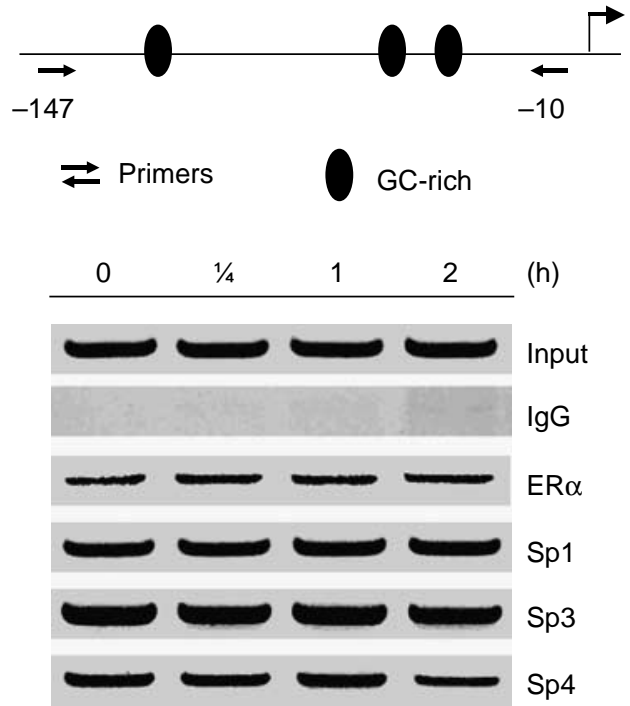

D

$C A D$ promoter
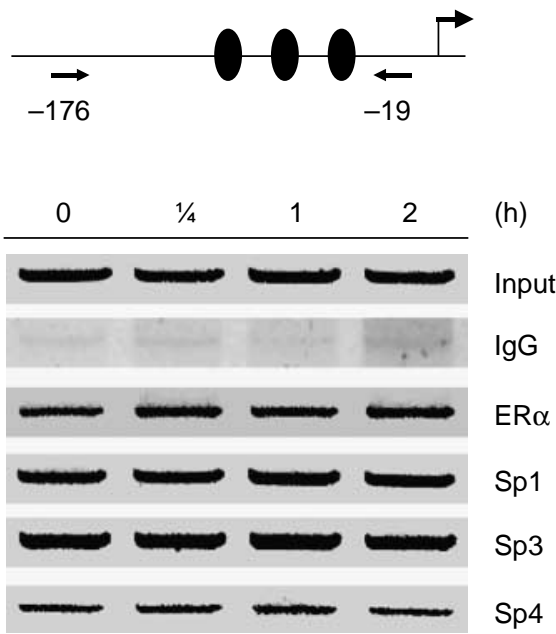

Figure $7 \mathrm{ChIP}$ assay of $\mathrm{ER} \alpha$ and $\mathrm{Sp}$ protein interactions with $\mathrm{E}_{2}$-responsive gene promoters. MCF7 cells were treated with $\mathrm{Me}_{2} \mathrm{SO}$ (D) or $10 \mathrm{nM} \mathrm{E}_{2}$ for different time points, and the interaction of $\mathrm{ER} \alpha$ and $S p$ proteins to the (A) pS2, (B) RAR $\alpha,(C) E_{2} F 1$, and (D) CAD gene promoters was determined in a ChIP assay as described in the Materials and methods. Similar results were obtained in duplicate experiments. We also observed specific binding of transcription factor IIB to the glyceraldehyde 3-phosphate dehydrogenase promoter and not to exon 1 of the CNAP1 gene (data not shown). This serves as an additional positive control for the ChIP assay (Higgins et al. 2006b).

are important for basal expression of the genes examined in this study, it is not surprising that these proteins are associated with these GC-rich promoters. These results are consistent with the known ligand-independent interactions of $\mathrm{ER} \alpha$ with Sp proteins (Porter et al. 1997, Saville et al. 2000, Stoner et al. 2000), and the colocalization of $\mathrm{ER} \alpha$ with $\mathrm{Sp} 1$ and $\mathrm{Sp} 4$ in $\mathrm{Me}_{2} \mathrm{SO}$ (and
$\mathrm{E}_{2}$ )-treated cells (Fig. 6). Moreover, we have recently reported similar $\mathrm{ER} \alpha$ and $\mathrm{Sp}$ interactions with the VEGFR2 promoter in ZR-75 cells using a ChIP assay (Higgins et al. 2006b). Our results demonstrate for the first time that hormonal activation of genes containing $E_{2^{-}}$ responsive GC-rich promoters in MCF-7 cells requires $\mathrm{ER} \alpha$ interactions with Sp1, Sp3, and Sp4. 


\section{Discussion}

The mechanism of ligand-dependent activation of nuclear receptors involves a simple concept in which receptor ligands induce formation of a transcriptionally active receptor complex bound to a cognate response element in the target gene promoter. However, transactivation mediated by nuclear receptors such as steroid hormone receptors is highly complicated and is dependent on ligand structure, hormone receptor subtype, tissue-specific expression of coactivators, other nuclear cofactors, and promoter context (Katzenellenbogen et al. 1996, Lemon \& Freedman 1999, Klinge 2000, Rosenfeld \& Glass 2001, Smith \& O'Malley 2004). For example, although $\mathrm{E}_{2}$ activates hormone-responsive gene expression in multiple tissues, other ER agonists such as the antiestrogen tamoxifen exhibit tissue-specific ER agonist and antagonist activities (Jordan 2003a,b). Differences between the activities of $\mathrm{E}_{2}$ and tamoxifen and other antiestrogens are due, in part, to their ligandinduced conformational changes in the ER and their subsequent differences in binding affinities for specific nuclear coactivators (Schwabe et al. 1993, Brzozowski et al. 1997, Shiau et al. 1998, 2002, Pike et al. 1999, Jordan 2003a).

ER/Sp1-dependent transactivation is also complex and dependent on multiple variables. For example, $\mathrm{E}_{2}$ activates $\mathrm{ER} \alpha / \mathrm{Sp}$ but not ER $\beta / \mathrm{Sp}$ in several different cell lines and in HeLa cells, $\mathrm{E}_{2}$ decreases $\mathrm{ER} \beta / \mathrm{Sp} 1-$ dependent transactivation and this may be a pathway for decreased gene expression by hormones (Saville $e t$ al. 2000). In addition, there is also evidence that activation of $\mathrm{ER} \alpha / \mathrm{Sp} 1$ involves multiple domains of $\mathrm{ER} \alpha$ and domain requirements are also dependent on the structure of the ER agonist (Saville et al. 2000, Kim et al. 2003). Previous studies have identified multiple gene promoters activated by $\mathrm{ER} \alpha / \mathrm{Sp}$ and Sp1 knockdown by RNA interference inhibits hormone-induced $\mathrm{G}_{0} / \mathrm{G}_{1}$ to $\mathrm{S}$-phase progression in MCF-7 cells (Abdelrahim et al. 2002). However, the role of individual $\mathrm{Sp} 1, \mathrm{Sp} 3$, and $\mathrm{Sp} 4$ proteins in mediating $\mathrm{ER} \alpha /$ Sp-induced gene expression in MCF-7 cells has not been determined. In this study, we have used RNA interference to investigate the effects of Sp protein knockdown (individual and combined) on induction of $\mathrm{E}_{2} \mathrm{~F} 1, \mathrm{RAR} \alpha$, and $\mathrm{CAD}$ gene expression by $\mathrm{E}_{2}$ since all three genes contain GC-rich promoters that are $\mathrm{E}_{2}$ -responsive in transfection studies (Wang et al. 1999, Khan et al. 2003, Ngwenya \& Safe 2003).

The siRNAs for Sp proteins are highly specific and have been used in several studies (Abdelrahim et al. 2002, 2004, Higgins et al. 2006a,b), and they efficiently decrease expression of both Sp1, Sp3, and Sp4 mRNA and protein (Fig. 1). The effects of iSps on basal luciferase activity in MCF-7 cells transfected with $\mathrm{pSp}_{3}, \mathrm{pE}_{2} \mathrm{~F} 1$ $(-169 /-54), \quad$ pCAD $(-90 /+25)$, and pRAR $\alpha$
$(-79 /-49)$ demonstrated that despite common GC-rich sites in all three promoters, decreased Sp protein expression differentially affected activity. Luciferase activity in cells transfected with $\mathrm{pE}_{2} \mathrm{~F} 1(-169 /-54)$ was decreased $\sim 70-90 \%$ after cotransfection with iSp1, iSp3, and iSp4, whereas in cells transfected with pRAR $\alpha$ $(-79 /-49)$, only iSp3 decreased activity and iSp1 actually increased activity. Although basal activity of the four promoters were differentially affected by Sp protein knockdown, $\mathrm{E}_{2}$-induced transactivation in cells transfected with these constructs, and fold induction was decreased in cells transfected with iSp1 or Sp4 (and their combinations), whereas iSp3 was the least effective or ineffective at decreasing fold induction. However, this may be, in part, due to the effects of iSp3 on decreasing basal activity in cells transfected with $\mathrm{iSp} 1_{3}, \mathrm{pRAR} \alpha$ $(-79 /-49)$, and $\mathrm{pE}_{2} \mathrm{~F} 1(-169 /-54)$. All three iSps induced a comparable decrease in basal activity in MCF-7 cells transfected with pCAD $(-90 /+25)$ and iSp3 also decreased hormone-induced activity with this construct. Transfected iSps significantly decreased induction of $\mathrm{E}_{2} \mathrm{~F} 1, \mathrm{RAR} \alpha$, and $\mathrm{CAD}$ mRNA levels by $\mathrm{E}_{2}$ in MCF-7 cells (Figs 3-5), and the order of effectiveness was iSp4 $\geq$ iSp3 $>$ iSp1. Knockdown of Sp3 resulted in a complete loss of hormone-induced RAR $\alpha$ mRNA, whereas in cells transfected with $\operatorname{pRAR} \alpha(-79 /-49)$, iSp3 did not affect $\mathrm{E}_{2}$-induced transactivation. This suggests that other GC-rich sites in the RAR $\alpha$ promoter are required for $\mathrm{ER} \alpha / \mathrm{Sp}$-mediated expression of this gene. Previous studies demonstrate that both Sp1 and Sp3 interact with ER $\alpha$ (Porter et al. 1996, 1997, Saville et al. 2000, Stoner et al. 2000) and we now show that both Sp1 and Sp4 colocalize with ER $\alpha$ in MCF-7 cells (Fig. 6). Thus, at least for the RAR $\alpha, \mathrm{CAD}$, and $\mathrm{E}_{2} \mathrm{~F} 1$ genes, all three $\mathrm{Sp}$ proteins play a role in $\mathrm{ER} \alpha / \mathrm{Sp}$-induced transactivation and, for $\mathrm{E}_{2} \mathrm{~F} 1$, we also showed decreased protein expression (Fig. 3).

The ChIP assay has been used extensively to investigate the ligand-induced assembly of ER $\alpha$ and other coactivators and nuclear cofactors on hormone-responsive gene promoters, and $\mathrm{pS} 2$ has been used extensively as a model for these studies (Shao et al. 2002, Metivier et al. 2003, Acevedo et al. 2004, Krieg et al. 2004, Sun et al. 2005). This gene has a well-characterized $\mathrm{E}_{2}$-responsive non-consensus ERE motif, and several studies have reported that treatment of MCF-7 cells with $\mathrm{E}_{2}$ recruits $\mathrm{ER} \alpha$ to the $\mathrm{pS} 2$ promoter. Similar results were observed in this study (Fig. 7A). Moreover, Sp1, Sp3, and Sp4 were also bound to the pS2 promoter, and PCR bands associated with the Sp protein-promoter interactions were not appreciably changed after treatment with $\mathrm{E}_{2}$. Sun et al. (2005)) also reported interactions of Sp1 and Sp3 with the pS2 promoter. Band intensities associated with Sp3-promoter interactions were unchanged after treatment with $\mathrm{E}_{2}$, whereas Sp1-promoter interactions were decreased; however, these changes were not observed in this study. 
We further investigated Sp protein interactions with the $\mathrm{E}_{2}$-responsive GC-rich regions of the $\mathrm{E}_{2} \mathrm{~F} 1, \mathrm{CAD}$, and RAR $\alpha$ promoters in a ChIP assay and observed interactions of Sp1, Sp3, and Sp4 with these promoters in untreated MCF-7 cells (Fig. 7B and D). After treatment of MCF-7 cells with $\mathrm{E}_{2}$, Sp protein-promoter interactions did not appreciably change, and this was similar to that observed for interactions of Sp proteins with the pS2 promoter (Fig. 7A). Binding of Sp1, Sp3, and Sp4 to the $\mathrm{CAD}, \mathrm{E}_{2} \mathrm{~F} 1$, and $\mathrm{RAR} \alpha$ promoters was similar in solvent and $\mathrm{E}_{2}$-treated cells, and this is consistent with the role of all three proteins in mediating basal expression and hormonal activation of $\mathrm{ER} \alpha / \mathrm{Sp}$-dependent $\mathrm{CAD}, \mathrm{E}_{2} \mathrm{~F} 1$, and RAR $\alpha$ mRNAs (Figs 3C, 4C, and 5C).

$\mathrm{ER} \alpha$ was also constitutively bound to the GC-rich promoters and, in contrast to observations with the pS2 promoter (Fig. 7A; Shao et al. 2002, Metivier et al. 2003, Acevedo et al. 2004, Krieg et al. 2004, Sun et al. 2005), $\mathrm{E}_{2}$ did not enhance $\mathrm{ER} \alpha$ interactions with the $\mathrm{CAD}, \mathrm{E}_{2} \mathrm{~F} 1$, and RAR $\alpha$ promoters in MCF-7 cells. Similar results were reported for the VEGFR2 promoter in ZR-75 cells (Higgins et al. 2006a) suggesting that there are fundamental differences in hormone-dependent interactions of $\mathrm{ER} \alpha$ with $\mathrm{E}_{2}$-responsive promoters containing GC-rich or ERE motifs. We have carried out ChIP assays on several GC-rich promoters under a variety of conditions but invariably find that $\mathrm{ER} \alpha, \mathrm{Sp} 1, \mathrm{Sp} 3$, and $\mathrm{Sp} 4$ are associated with these promoters in the presence or absence of $E_{2}$. These results suggest that there may also be differences in the recruitment of other nuclear cofactors to these gene promoters, and promoterdependent differences in coactivator recruitment are currently being investigated.

In summary, results of this study demonstrate that Sp1, Sp3, and Sp4 transcription factors are important for hormone-induced $\mathrm{E}_{2} \mathrm{~F} 1, \mathrm{CAD}$, and RAR $\alpha$ mRNA expression. This is the first report showing the different contributions of $\mathrm{ER} \alpha / \mathrm{Sp} 1, \mathrm{ER} \alpha / \mathrm{Sp} 3$, and $\mathrm{ER} \alpha / \mathrm{Sp} 4$ on hormone-induced transactivation in MCF-7 cells. The relative effects of these individual proteins on $\mathrm{ER} \alpha / \mathrm{Sp}-$ mediated transactivation were dependent on the specific gene and gene promoter. Basal activity of the GC-rich proximal promoter regions of the $\mathrm{E}_{2} \mathrm{~F} 1, \mathrm{CAD}$, and $\mathrm{RAR} \alpha$ were differentially effected by $\mathrm{Sp}$ protein knockdown (Figs 3A, 4A, and 5A) and activity in cells transfected with pRAR $\alpha-2$ was only minimal decreased by iSps. Despite these differences, results of ChIP assays show that Sp1, Sp3, Sp4, and ER $\alpha$ were associated with all three promoters in the absence or presence of $\mathrm{E}_{2}$ (Fig. 7). In ongoing studies, we are further analyzing interactions of $\mathrm{ER} \alpha$ and Sp proteins with the $\mathrm{E}_{2} \mathrm{~F} 1, \mathrm{RAR} \alpha, \mathrm{CAD}$, and other gene promoters and comparing their binding to $\mathrm{E}_{2}$-responsive and non-responsive promoter sequences. We are also investigating the effects of ligand structure, coactivators, and cell context on this important genomic pathway of estrogen action using both cell culture and in vivo models.

\section{Acknowledgements}

The financial assistance of the National Institutes of Health (ES09106, ES04917, and CA104116), the Department of the Defense (DAMD17-03-1-0341), and the Texas Agricultural Experiment Station is gratefully acknowledged. The authors declare that there is no conflict of interest that would prejudice the impartiality of this scientific work.

\section{Disclosure statement}

The authors have nothing to disclose.

\section{References}

Abdelrahim M, Samudio I, Smith R, Burghardt R \& Safe S 2002 Small inhibitory RNA duplexes for Spl mRNA block basal and estrogeninduced gene expression and cell cycle progression in MCF-7 breast cancer cells. Journal of Biological Chemistry 277 28815-28822.

Abdelrahim M, Smith R, III, Burghardt R \& Safe S 2004 Role of Sp proteins in regulation of vascular endothelial growth factor expression and proliferation of pancreatic cancer cells. Cancer Research 64 6740-6749.

Acevedo ML, Lee KC, Stender JD, Katzenellenbogen BS \& Kraus WL 2004 Selective recognition of distinct classes of coactivators by a ligand-inducible activation domain. Molecular Cell 13 725-738.

Bardin A, Moll F, Margueron R, Delfour C, Chu ML, Maudelonde T, Cavailles V \& Pujol P 2005 Transcriptional and posttranscriptional regulation of fibulin-1 by estrogens leads to differential induction of messenger ribonucleic acid variants in ovarian and breast cancer cells. Endocrinology 146 760-768.

Blobel GA \& Orkin SH 1996 Estrogen-induced apoptosis by inhibition of the erythroid transcription factor GATA-1. Molecular and Cellular Biology 16 1687-1694.

Bruning JC, Lingohr P, Gillette J, Hanstein B, Avci H, Krone W, MullerWieland D \& Kotzka J 2003 Estrogen receptor- $\alpha$ and Sp1 interact in the induction of the low density lipoprotein-receptor. Journal of Steroid Biochemistry and Molecular Biology 86 113-121.

Brzozowski AM, Pike AC, Dauter Z, Hubbard RE, Bonn T, Engstrom O, Ohman L, Greene GL, Gustafsson JA \& Carlquist M 1997 Molecular basis of agonism and antagonism in the oestrogen receptor. Nature 389 753-758.

Byrne IM, Flanagan L, Tenniswood MP \& Welsh J 2000 Identification of a hormone-responsive promoter immediately upstream of exon $1 \mathrm{c}$ in the human vitamin D receptor gene. Endocrinology 141 2829-2836.

Castro-Rivera E, Samudio I \& Safe S 2001 Estrogen regulation of cyclin D1 gene expression in ZR-75 breast cancer cells involves multiple enhancer elements. Journal of Biological Chemistry 276 30853-30861.

Chow J, Tobias JH \& Colston KW 1992 Estrogen maintains trabecular bone volume in rats not only by suppression of bone resorption but also by stimulation of bone formation. Journal of Clinical Investigation 89 74-78.

Clark JH 1998 Female reproduction and toxicology of estrogens. In Reproductive and Developmental Toxicology, pp 259-275. Ed KS Korach. New York: Marcel Dekker. 
Cowley SM, Hoare S, Mosselman S \& Parker MG 1997 Estrogen receptors $\alpha$ and $\beta$ form heterodimers on DNA. Journal of Biological Chemistry 272 19858-19862.

Delfino F \& Walker WH 1999 Hormonal regulation of the NF-кB signaling pathway. Molecular and Cellular Endocrinology 157 1-9.

Dong L, Wang W, Wang F, Stoner M, Reed JC, Harigai M, Kladde M, Vyhlidal C \& Safe S 1999 Mechanisms of transcriptional activation of $b c l-2$ gene expression by $17 \beta$-estradiol in breast cancer cells. Journal of Biological Chemistry 174 32099-32107.

Duan R, Porter W \& Safe S 1998 Estrogen-induced $c$-fos protooncogene expression in MCF-7 human breast cancer cells: role of estrogen receptor Sp1 complex formation. Endocrinology 139 1981-1990.

Farhat MY, Lavigne MC \& Ramwell PW 1996 The vascular protective effects of estrogen. FASEB Journal 10 615-624.

Fujita N, Kajita M, Taysavang P \& Wade PA 2004 Hormonal regulation of metastasis-associated protein 3 transcription in breast cancer cells. Molecular Endocrinology 18 2937-2949.

Hall JM, Couse JF \& Korach KS 2001 The multifaceted mechanisms of estradiol and estrogen receptor signaling. Journal of Biological Chemistry 276 36869-36872.

Higgins KJ, Abdelrahim M, Liu S, Yoon K \& Safe S 2006a Regulation of vascular endothelial growth factor receptor-2 expression in pancreatic cancer cells by Sp proteins. Biochemical and Biophysical Research Communications 345 292-301.

Higgins KJ, Liu S, Abdelrahim M, Yoon K, Vanderlaag K, Porter W, Metz RP $\&$ Safe S 2006bVascular endothelial growth factor receptor-2 expression is induced by $17 \beta$-estradiol in ZR-75 breast cancer cells by estrogen receptor $\alpha /$ Sp proteins. Endocrinology 147 3285-3295.

Hyder SM, Chiappetta C \& Stancel GM 1999 Interaction of human estrogen receptors alpha and beta with the same naturally occurring estrogen response elements. Biochemical Pharmacology 57 597-601.

Jacobson D, Pribnow D, Herson PS, Maylie J \& Adelman JP 2003 Determinants contributing to estrogen-regulated expression of SK3. Biochemical and Biophysical Research Communications 303 660-668.

Jordan VC 2003a Antiestrogens and selective estrogen receptor modulators as multifunctional medicines. 1. Receptor interactions. Journal of Medicinal Chemistry 46 883-908.

Jordan VC $2003 b$ Antiestrogens and selective estrogen receptor modulators as multifunctional medicines. 2. Clinical considerations and new agents. Journal of Medicinal Chemistry 46 1081-1111.

Katzenellenbogen JA, O’Malley BW \& Katzenellenbogen BS 1996 Tripartite steroid hormone receptor pharmacology - interaction with multiple effector sites as a basis for the cell- and promoter-specific action of these hormones. Molecular Endocrinology 10 119-131.

Kelly MJ \& Wagner EJ 1999 Estrogen modulation of G-protein-coupled receptors. Trends in Endocrinology and Metabolism 10 369-374.

Khan S, Abdelrahim M, Samudio I \& Safe S 2003 Estrogen receptor/Sp1 complexes are required for induction of cad gene expression by $17 \beta$ estradiol in breast cancer cells. Endocrinology 144 2325-2335.

Kim K, Thu N, Saville B \& Safe S 2003 Domains of estrogen receptor $\alpha$ $(\mathrm{ER} \alpha)$ required for $\mathrm{ER} \alpha / \mathrm{Sp} 1-$ mediated activation of GC-rich promoters by estrogens and antiestrogens in breast cancer cells. Molecular Endocrinology 17 804-817.

Kim K, Barhoumi R, Burghardt R \& Safe S 2005 Analysis of estrogen receptor $\alpha$-Spl interactions in breast cancer cells by fluorescence resonance energy transfer. Molecular Endocrinology 19 843-854.

Klein-Hitpass L, Schorpp M, Wagner U \& Ryffel GU 1986 An estrogenresponsive element derived from the $5^{\prime}$-flanking region of the xenopus vitellogenin A2 gene functions in transfected human cells. Cell 46 1053-1061.

Klinge CM 2000 Estrogen receptor interactions with co-activators and corepressors. Steroids 65 227-251.

Krege JH, Hodgin JB, Couse JF, Enmark E, Warner M, Mahler JF, Sar M, Korach KS, Gustafsson JA \& Smithies O 1998 Generation and reproductive phenotypes of mice lacking estrogen receptor $\beta$. PNAS 95 15677-15682.
Krieg AJ, Krieg SA, Ahn BS \& Shapiro DJ 2004 Interplay between estrogen response element sequence and ligands controls in vivo binding of estrogen receptor to regulated genes. Journal of Biological Chemistry 279 5025-5034.

Kushner PJ, Agard DA, Greene GL, Scanlan TS, Shiau AK, Uht RM \& Webb P 2000 Estrogen receptor pathways to AP-1. Journal of Steroid Biochemistry and Molecular Biology 74 311-317.

Lemon BD \& Freedman LP 1999 Nuclear receptor cofactors as chromatin remodelers. Current Opinion in Genetics and Development 9 499-504.

Levin ER 2005 Integration of the extranuclear and nuclear actions of estrogen. Molecular Endocrinology 19 1951-1959.

Li C, Briggs MR, Ahlborn TE, Kraemer FB \& Liu J 2001 Requirement of Spl and estrogen receptor $\alpha$ interaction in $17 \beta$-estradiol-mediated transcriptional activation of the low density lipoprotein receptor gene expression. Endocrinology 142 1546-1553.

Matthews J \& Gustafsson JA 2003 Estrogen signaling: a subtle balance between ER $\alpha$ and ER $\beta$. Molecular Interventions 3 281-292.

Metivier R, Penot G, Hubner MR, Reid G, Brand H, Kos M \& Gannon F 2003 Estrogen receptor- $\alpha$ directs ordered, cyclical, and combinatorial recruitment of cofactors on a natural target promoter. Cell 115 751-763.

Ngwenya S \& Safe S 2003 Cell context-dependent differences in the induction of $\mathrm{E}_{2} \mathrm{~F}-1$ gene expression by $17 \beta$-estradiol in MCF-7 and ZR-75 cells. Endocrinology 144 1675-1685.

Nilsson S \& Gustafsson JA 2002 Biological role of estrogen and estrogen receptors. Critical Reviews in Biochemistry and Molecular Biology 37 1-28.

Olefsky JM 2001 Nuclear receptor minireview series. Journal of Biological Chemistry 276 36863-36864.

Pike AC, Brzozowski AM, Hubbard RE, Bonn T, Thorsell AG, Engstrom O, Ljunggren J, Gustafsson JA \& Carlquist M 1999 Structure of the ligand-binding domain of oestrogen receptor beta in the presence of a partial agonist and a full antagonist. EMBO Journal 18 4608-4618.

Porter W, Wang F, Wang W, Duan R \& Safe S 1996 Role of estrogen receptor/Sp1 complexes in estrogen-induced heat shock protein 27 gene expression. Molecular Endocrinology 10 1371-1378.

Porter W, Saville B, Hoivik D \& Safe S 1997 Functional synergy between the transcription factor $\mathrm{Spl}$ and the estrogen receptor. Molecular Endocrinology 11 1569-1580.

Qin C, Singh P \& Safe S 1999 Transcriptional activation of insulin-like growth factor binding protein 4 by $17 \beta$-estradiol in MCF-7 cells: role of estrogen receptor-Spl complexes. Endocrinology 140 2501-2508.

Razandi M, Pedram A, Merchenthaler I, Greene GL \& Levin ER 2004 Plasma membrane estrogen receptors exist and functions as dimers. Molecular Endocrinology 18 2854-2865.

Rosenfeld MG \& Glass CK 2001 Coregulator codes of transcriptional regulation by nuclear receptors. Journal of Biological Chemistry 276 $36865-36868$.

Safe S \& Kim K 2004 Nuclear receptor-mediated transactivation through interaction with Sp proteins. Progress in Nucleic Acid Research and Molecular Biology 77 1-36.

Salvatori L, Ravenna L, Felli MP, Cardillo MR, Russo MA, Frati L, Gulino A \& Petrangeli E 2000 Identification of an estrogen-mediated deoxyribonucleic acid-binding independent transactivation pathway on the epidermal growth factor receptor gene promoter. Endocrinology $1412266-2274$.

Samudio I, Vyhlidal C, Wang F, Stoner M, Chen I, Kladde M, Barhoumi R, Burghardt R \& Safe S 2001 Transcriptional activation of DNA polymerase $\alpha$ gene expression in MCF-7 cells by $17 \beta$-estradiol. Endocrinology 142 1000-1008.

Saville B, Wormke M, Wang F, Nguyen T, Enmark E, Kuiper G, Gustafsson J-A \& Safe S 2000 Ligand-, cell- and estrogen receptor subtype $(\alpha / \beta)$-dependent activation at GC-rich $(\mathrm{Sp} 1)$ promoter elements. Journal of Biological Chemistry 275 5379-5387.

Schultz JR, Petz LN \& Nardulli AM 2003 Estrogen receptor $\alpha$ and Spl regulate progesterone receptor gene expression. Molecular and Cellular Endocrinology 201 165-175. 
Schultz JR, Petz LN \& Nardulli AM 2005 Cell- and ligand-specific regulation of promoters containing activator protein-1 and Sp1 sites by estrogen receptors $\alpha$ and $\beta$. Journal of Biological Chemistry $\mathbf{2 8 0}$ $347-354$.

Schwabe JW, Chapman L, Finch JT \& Rhodes D 1993 The crystal structure of the estrogen receptor DNA-binding domain bound to DNA: how receptors discriminate between their response elements. Cell 75 567-578.

Shao W, Halachmi S \& Brown M 2002 ERAP140, a conserved tissuespecific nuclear receptor coactivator. Molecular and Cellular Biology 22 $3358-3372$

Shiau AK, Barstad D, Loria PM, Cheng L, Kushner PJ, Agard DA \& Greene GL 1998 The structural basis of estrogen receptor/coactivator recognition and the antagonism of this interaction by tamoxifen. Cell 95 927-937.

Shiau AK, Barstad D, Radek JT, Meyers MJ, Nettles KW, Katzenellenbogen BS, Katzenellenbogen JA, Agard DA \& Greene GL 2002 Structural characterization of a subtype-selective ligand reveals a novel mode of estrogen receptor antagonism. Nature Structural Biology 9 359-364.

Smith CL \& O'Malley BW 2004 Coregulator function: a key to understanding tissue specificity of selected receptor modulators. Endocrine Reviews 25 45-71.

Stoner M, Wang F, Wormke M, Nguyen T, Samudio I, Vyhlidal C, Marme D, Finkenzeller G \& Safe S 2000 Inhibition of vascular endothelial growth factor expression in HEClA endometrial cancer cells through interactions of estrogen receptor $\alpha$ and Sp3 proteins. Journal of Biological Chemistry 275 22769-22779.

Stoner M, Wormke M, Saville B, Samudio I, Qin C, Abdelrahim M \& Safe S 2004 Estrogen regulation of vascular endothelial growth factor gene expression in ZR-75 breast cancer cells through interaction of estrogen receptor $\alpha$ and Sp proteins. Oncogene 23 1052-1063.

Sun G, Porter W \& Safe S 1998 Estrogen-induced retinoic acid receptor $\alpha 1$ gene expression: role of estrogen receptor-Sp1 complex. Molecular Endocrinology 12 882-890.

Sun JM, Spencer VA, Li L, Yu CH, Yu J \& Davie JR 2005 Estrogen regulation of trefoil factor 1 expression by estrogen receptor $\alpha$ and Sp proteins. Experimental Cell Research 302 96-107.

Tanaka N, Yonekura H, Yamagishi S, Fujimori H, Yamamoto Y \& Yamamoto H 2000 The receptor for advanced glycation end products is induced by the glycation products themselves and tumor necrosis factor- $\alpha$ through nuclear factor- $\kappa \mathrm{B}$, and by $17 \beta$-estradiol through Sp-1 in human vascular endothelial cells. Journal of Biological Chemistry 275 25781-25790.

Turner RT, Riggs BL \& Spelsberg TC 1994 Skeletal effects of estrogen. Endocrine Reviews 15 275-300.

Wang W, Dong L, Saville B \& Safe S 1999 Transcriptional activation of $\mathrm{E}_{2} \mathrm{~F} 1$ gene expression by $17 \beta$-estradiol in MCF-7 cells is regulated by NF-Y-Sp1/estrogen receptor interactions. Molecular Endocrinology 13 1373-1387.

Wang F, Samudio I \& Safe S 2002 Transcriptional activation of rat creatine kinase B by 17ß-estradiol in MCF-7 cells involves an estrogen responsive element and GC-rich sites. Journal of Cellular Biochemistry 84 156-172.

Watson CS, Campbell CH \& Gametchu B 2002 The dynamic and elusive membrane estrogen receptor- $\alpha$. Steroids 67 429-437.

Weihua Z, Saji S, Makinen S, Cheng G, Jensen EV, Warner M \& Gustafsson JA 2000 Estrogen receptor (ER) $\beta$, a modulator of ER $\alpha$ in the uterus. PNAS 97 5936-5941.

Xie W, Duan R \& Safe S 1999 Estrogen induces adenosine deaminase gene expression in MCF-7 human breast cancer cells: role of estrogen receptor-Sp1 interactions. Endocrinology 140 219-227.

Xie W, Duan R, Chen I, Samudio I \& Safe S 2000 Transcriptional activation of thymidylate synthase by $17 \beta$-estradiol in MCF-7 human breast cancer cells. Endocrinology 141 2439-2449.

Zhao YL, Han WD, Li Q, Mu YM, Lu XC, Yu L, Song HJ, Li X, Lu JM \& Pan CY 2005 Mechanism of transcriptional regulation of LRP16 gene expression by $17-\beta$ estradiol in MCF-7 human breast cancer cells. Journal of Molecular Endocrinology 34 77-89.

Received in final form 3 July 2007

Accepted 7 August 2007

Made available online as an Accepted Preprint 14 August 2007 